\title{
Earliest life on Earth: Evidence from the Barberton Greenstone Belt, South Africa
}

\author{
Homann Martin 1, * \\ ${ }^{1}$ CNRS, UMR6538, Technopole Brest Iroise, European Inst Marine Studies,Lab Geosci Ocean, F- \\ 29280 Plouzane, France. \\ * Corresponding author : Martin Homann, email address : martin.homann@univ-brest.fr
}

\begin{abstract}
:
Studies investigating the structure and diversity of Earth's record of life older than $3.2 \mathrm{Ga}$ are restricted to two locations worldwide in which sedimentary rocks have escaped regional high-grade metamorphism and penetrative deformation: the Pilbara Craton of Western Australia and the Barberton Greenstone Belt in the Kaapvaal Craton of South Africa. This paper provides a South African perspective on the evidence of Paleoarchean life; a record that is often overlooked in the literature. It aims to summarize and critically review previously reported claims of early life in the BGB, gives an overview of the latest findings, and provides an outlook on potential future discoveries.
\end{abstract}

The similar to $15 \mathrm{~km}$ thick, volcanic-sedimentary succession making up the Barberton Supergroup was deposited between 3.55 to ca. $3.20 \mathrm{Ga}$ and can be subdivided in three stratigraphic units that provide a unique window into a diverse and widespread Paleoarchean microbial ecosystem landscape. Putative biosignatures occur almost throughout the entire BGB stratigraphy and range from carbonaceous cherts containing filamentous, spheroidal, and lenticular microstructures, traces of hydrothermal biofilms, photosynthetic microbial mats, remnants of pseudocolumnar stromatolites, and large, organic-walled spheroidal microfossils of currently unknown affinity. The BGB also contains one of the world's oldest known record of tufted microbial mats, which extensively colonized tidally-influenced, siliciclastic shorelines and were most likely formed by filamentous photosynthesizers. Other mat-associated biosignatures include silicified gas bubbles, domes and lenses that likely formed due to metabolic activity or the decay of buried organic matter. Some of these subsurface voids beneath the cohesive mats were inhabited by the earliest known forms of cavity-dwelling microbial communities that were probably dominated by chemotrophic or photosynthetic microbes. Recently discovered terrestrial microbial mats, once thriving in a fluvial-dominated setting, represent the oldest macroscopically-visible fossil traces of life on land, which is also supported by the occurrence of nearby paleosols that carry signals of biogenic sulfur fractionation.

The wealth of preserved microbial biosignatures from marine, fluvial, hydrothermal, and possibly planktonic settings combined with the high spatial and temporal resolution of the Barberton Greenstone Belt deposits is truly exceptional, Consequently, the BGB deserves an equal level of attention and protection for future generations like its Australian counterpart. 


\section{1. Introduction}

38 The Archean rock record is sparse, largely metamorphosed, and preserved in fragmented Greenstone Belts, 39 which occur wedged in between plutonic and metamorphic rocks in the cratonic lithosphere of nearly all continents. However, only the Barberton Greenstone Belt (BGB) of South Africa and Swaziland and the contemporaneous Pilbara Greenstone Belts (PGBs) of Western Australia contain well-preserved sedimentary rocks of Paleoarchean age $(>3.2 \mathrm{Ga})$, which experienced only greenschist facies metamorphism and relatively minor deformation. With an aerial extend of $\sim 6000 \mathrm{~km}^{2}$ and an age of $\sim 3.55-$ $3.20 \mathrm{Ga}$ the BGB is significantly smaller and captures a slightly shorter time interval in comparison to the PGBs ( $\left.\sim 60000 \mathrm{~km}^{2}, \sim 3.52-2.94 \mathrm{Ga}\right)$, however, the deposits preserved in the BGB are characterized by often laterally consistent outcrops with correlatable facies, a generally better exposure, and very good accessibility. Lithified aquatic sediments in both of these volcano-sedimentary "enclaves" are considered the most suitable archive of ancient microbial life, as water is one of the fundamental requirements for life. Consequently, the sedimentary deposits have been extensively studied for traces of early life in these two localities and the reported findings have been critically reviewed especially for the Pilbara Greenstone Belts, where stromatolites, microfossils, and isotopic signals belong to the most dominant biosignatures (e.g. Allwood et al., 2006; Brasier et al., 2006; Wacey, 2009, 2012). The focus of this study here is to summarize and review the South African evidence of Paleoarchean life reported from the BGB, place them in a consistent stratigraphic framework, and discuss and evaluate the most recent findings.

\section{Geology of the BGB}

8 The Barberton Greenstone Belt of South Africa and Swaziland is located at the eastern margin of the Kaapvaal Craton and contains volcanic, shallow intrusive, and sedimentary rocks, ranging in age from $<3.547$ to $>3.219 \mathrm{Ga}$ (Byerly et al., 2019; Fig. 1). These age constrains are mainly derived from highprecision zircon $\mathrm{U}-\mathrm{Pb}$ age dating of interbedded volcanic units and plutons surrounding the $\mathrm{BGB}$, as well as detrital zircon geochronology. Rocks of the Barberton Supergroup (formerly named Swaziland Supergroup), are subdivided from base to top into three lithostratigraphic units: (1) the $\sim 8-10 \mathrm{~km}$ thick, volcanic-dominated Onverwacht Group, which comprises the Komati, Hooggenoeg, Kromberg, and Mendon Formations (Viljoen and Viljoen, 1969; Anhaeusser, 1976; Lowe and Byerly, 2007; De Wit and Furnes, H., 2011); (2) the up to $\sim 2 \mathrm{~km}$ thick Fig Tree Group, predominantly composed of interlayered volcaniclastic strata that mark the final stages of major volcanism and the transition to deposition of terrigenous clastic units (Heinrichs and Reimer, 1977; Lowe, 1999a; Hofmann, 2005; Byerly et al., 2019); and (3) the up to $3.5 \mathrm{~km}$ thick, coarse-grained siliciclastic to conglomeritic Moodies Group, mainly derived 
from the erosion of underlying units and uplifted plutonic rocks (Eriksson, 1977; Heubeck and Lowe, 1994a, 1994b, 1999). The dominant large-scale orogeny of the BGB occurred contemporaneously with 72 deposition of the Moodies Group at 3.225-3.215 Ga (Lamb and Paris, 1988; Heubeck et al., 2013). 73 Although the BGB strata experienced several phases of major deformation during which they were folded, 74 faulted and altered, the rocks are generally well-preserved in locally very thick and laterally-traceable sections (De Ronde and De Wit, 1994; Toulkeridis et al., 1998; Lowe and Byerly, 1999). A major fault system, the Inyoka Fault, transects the BGB approximately medially and divides it into a northern and southern facies, characterized by distinct differences in the preserved stratigraphy and depositional facies of especially the Onverwacht and Fig Tree Groups (Fig. 2). Although approximately coeval, these deposits represent previously geographically separated successions that are now in tectonic contact with another (Byerly et al., 2019). The greenstone belt fill can be further subdivided into several tectonostratigraphic blocks, each bordered by numerous, steeply dipping large and small faults (Lowe, 1999a; Lowe et al., 2012). Most rocks in the central part of the BGB experienced alteration temperatures of $>300^{\circ} \mathrm{C}$ (Xie et al., 1997; Toulkeridis et al., 1998; Tice et al., 2004), however some primary minerology, textures, and sedimentary structures have been preserved in many units due to the combination of early silicification and the local partitioning of strain (Byerly et al., 2019).

\section{History of early life studies in the BGB}

The BGB has a long history of studies focusing on traces of early life and the reconstruction of its habitat, metabolism, biogeochemical cycling, and mode of preservation (Table 1). Since the mid-1960s the occurrence of lenticular, spheroidal, and filamentous microstructures, interpreted as possible cellular microfossils, has been reported from carbonaceous cherts of the Onverwacht Group* (Barghoorn and Schopf, 1966; Pflug, 1966, 1967; Schopf and Barghoorn, 1967; Pflug et al., 1969; Barghoorn, 1971). *[Note that these samples were collected from the same outcrop, which was originally assigned to the Fig Tree Group, but later revised and changed to the upper Onverwacht Group (Pflug, 1967; Schopf, 1975; Lowe and Knauth, 1977).] In the following years simple spherical and filamentous microstructures have also been described from other Onverwacht Group cherts of the Mendon and Kromberg Formation (Engel et al., 1968; Nagy and Nagy, 1969; Brooks and Shaw, 1971; Brooks et al., 1973; Muir and Hall, 1974; Muir and Grant, 1976; Knoll and Barghoorn, 1977), however the exact stratigraphic position was often not clearly indicated, which made it challenging to put the individual findings in context to each other. In fact, the insufficient knowledge of the BGB stratigraphy at that time and the often poorly studied depositional facies, and paleoenvironmental context of the analyzed samples are central problems of most of these pioneering studies. Due to their often simply morphology and wide size range the biogenicity of almost all of the early- 
reported microfossils has been questioned in several reviews (Schopf, 1975; Schopf and Walter, 1983;

105

106

107

108

109

110

111

112

113

114

115

116

117

118

119

120

121

122

123

124

125

126

127

128

129

130

131

132

133

134

135

136

137

Altermann, 2001; Wacey, 2009), which suggested that except for the structures described by Muir and Grant (1976) and Knoll and Barghoorn (1977) all other findings should be treated as nonfossil artefacts, aggregates of amorphous carbonaceous matter or modern contaminants. More detailed sedimentological, geochronological, and tectonostratigraphic investigations of the BGB deposits (Lowe and Knauth, 1977; Kröner et al., 1991; Lowe and Byerly, 1999; Lowe et al., 2012), organic carbon isotope analysis (e.g. Oehler et al., 1972), the identification of possible stromatolites (de Wit et al., 1982; Byerly et al., 1986; Byerly and Palmer, 1991; Walsh, 2004), and new discoveries of mat-like laminations, lenticular, spheroidal, and filamentous microfossil in cherts of the Hooggenoeg, Kromberg, and Mendon Formations (Walsh and Lowe, 1985, 1999; Walsh, 1992; Westall et al., 2001; Glikson et al., 2008) supported previous findings (e.g. Pflug, 1966; Knoll and Barghoorn, 1977) and stimulated further investigations. In the following, carbonaceous laminations preserved in the shallow-water facies of the Buck Reef Chert (Kromberg Formation) have been studied in great detail and were interpreted as the remains of photosynthetic microbial mats (Tice and Lowe, 2004, 2006a, 2006b; Tice, 2009; Tice et al., 2011). Westall et al. (2006, 2011, 2015, 2018) identified microbial biofilms and possible fossil bacteria in the Josefsdal Chert (Kromberg Formation) and suggested that these microbial communities were once thriving in a nearshore hydrothermal setting. Tubular, titanite-mineralized microstructures in basaltic pillow lava rims of the Hooggenoeg and Kromberg Formations were interpreted as being the result of microbial etching, and thus indicating the presence of submarine thermophilic microbial communities during basalt formation (Furnes, 2004; Banerjee et al., 2007; Furnes et al., 2007; Fliegel et al., 2010). However, the syngenicity and biogenicity of these putative oldest trace fossils has been strongly questioned and is currently still under debate (Mcloughlin et al., 2012; Grosch and McLoughlin, 2014; Staudigel et al., 2015; Wacey et al., 2017; Hickman-Lewis et al., 2019 for a short review). More recently, the biogenicity of lenticular microfossils from the Kromberg Formation was further supported by in situ carbon isotope analysis (Oehler et al., 2017), while new findings of cell-like objects from the Buck Reef Chert were interpreted as degraded colonies of coccoidal bacteria (Kremer and Kaźmierczak, 2017). Moreover, Hickman-Lewis et al. (2018) reported carbonaceous laminations, resembling microbial biofilms and mats from the Middle Marker at the base of the Hooggenoeg Formation, making it to the most ancient claim for life in the BGB.

In the last decade also the sand- and siltstones of Moodies Group (uppermost unit of the BGB), were carefully investigated for traces of early microbial life, which resulted in the discovery of large spheroidal microfossils (Javaux et al., 2010), widespread shallow-marine tufted microbial mats once formed by photosynthetic microorganisms (Noffke et al., 2006; Heubeck, 2009; Gamper et al., 2012; Homann et al., 2015) and remnants of cavity-dwelling microbial communities (Homann et al., 2016). Terrestrial microbial mats interbedded with fluvial sandstones and conglomerates, record a significant difference in their organic 
carbon and nitrogen isotopes in comparison with the tidal marine mats and represent the oldest macroscopically-visible trace of life on land (Homann et al., 2018). The presence of a Paleoarchean

140 terrestrial biosphere is further supported by the Moodies Group paleosols that carry signals of biogenic 141 sulfur fractionation (Nabhan et al., 2016a, 2016b). In the following, a selection of the most promising and 142 best documented claims for early life from the Onverwacht and Moodies Groups of the BGB will be 143 described and discussed in more detail.

\section{The 3.55-3.26 Onverwacht Group}

147 volcanic rocks with minor felsic volcanic flow units and tuffs (Lowe and Byerly, 1999). Subordinate 148 sedimentary units formed during episodic breaks in eruptive activity and have been widely silicified to 149 bedded cherts, which host a large number of the reported traces of early life in the BGB, including microbial 150 mats, microfossils, and possible stromatolites. Moreover, rare asteroid ejecta layers, composed of impact 151 spherules, fine ash and dust, locally occur as discrete beds and record distal impact events of large asteroids 152 with diameters ranging between 20-50 km (Fig. 2; Lowe and Byerly, 1986, 2018). The Onverwacht Group 153 comprises four different formations (Komati, Hooggenoeg, Kromberg, and Mendon), which each can be 154 further subdivided into informal members (e.g. H1 - H6). Within each member the cherts, which are capping 155 individual volcanic units are designated with a "c" (e.g. H4c; Lowe and Byerly, 1999; Byerly et al., 2019). 156 Overlying the basal Komati Formation, the 3.472 - 3.416 Ga Hooggenoeg Formation consists of thick 157 sequence of tholeiitic basalts, minor komatiites, and thin chert units and can reach a thickness of up to 3900 $158 \mathrm{~m}$ on the western limb of the Onverwacht Anticline (Viljoen and Viljoen, 1969b, Lowe and Byerly, 1999). 159 The 3.416 - 3.334 Ga Kromberg Formation on the west limb of the Onverwacht Anticline comprises an up 160 to 1800-m-thick succession of black and banded chert (Buck Reef Chert, K1), mafic lapilli tuff and 161 lapillistone (K2), and tholeiitic basalt (K3), while on the eastern limb of the anticline massive pillow basalt 162 is more abundant. The top of the formation is marked by a regionally traceable chert unit, the Footbridge 163 Chert (K3c; Viljoen and Viljoen, 1969, Lowe and Byerly, 1999). Conformably overlying the Kromberg 164 Formation, the $3.334-3258 \mathrm{Ga}$ Mendon Formation has a thickness of $>600 \mathrm{~m}$ and records an alternation of 165 volcanic cycles, each characterized by a komatiitic flow unit capped by a chert layer (Byerly, 1999).

\section{4.1 Microbial mats}

168 The first systematic stratigraphic and petrographic analysis of all carbonaceous cherts in the Hooggenoeg, 169 Kromberg, and Mendon Formation of the Onverwacht Group was made by Walsh (1992) and Walsh and 170 Lowe (1999), who distinguished three main types: black-and-white banded, massive black, and black 171 laminated chert. The carbonaceous matter in these cherts occurs mostly in the form of: fine laminations (1 
$172-20 \mu \mathrm{m}$ thick), carbonaceous wisps (10-50 $\mu \mathrm{m}$ thick, 50-1000 $\mu \mathrm{m}$ long) that are likely eroded fragments 173 of the fine laminations, subrounded composite grains $(100-1000 \mu \mathrm{m})$, and irregular-shaped simple grains $174(5-750 \mu \mathrm{m})$, and. Based on bulk $\delta^{13} \mathrm{C}_{\mathrm{org}}$ values ranging between $-40.8 \%$ and $-16.9 \%$, with a mean of $175-29.8 \%$ o $(\mathrm{n}=50)$, Walsh and Lowe (1999) concluded that all the carbonaceous matter in the cherts is 176 probably of biological origin, which was further supported by a detailed study of van Zuilen et al. (2007), 177 combining Raman spectroscopy and SIMS (secondary ion mass spectrometry) analysis.

178 In detail, the fine carbonaceous laminations that form layers of $0.5-2 \mathrm{~cm}$ thickness and occur predominantly 179 in black-and-white banded cherts the Hooggenoeg (H2, H4c, H5c), Kromberg (K1, K3c), and Mendon 180 Formation (M1c, M2c), were interpreted as remains of microbial mats (Walsh, 1992; Walsh and Lowe, 181 1999; Trower and Lowe, 2016). The alternation of carbonaceous black bands with thin layers of pure 182 (white) quartz in these cherts is likely comparable with alternating organic-rich and organic-poor sediments 183 in modern microbial mats. The mats presumably formed in periods of volcanic quiescence but likely under 184 the presence of hydrothermal activity. They are often interbedded with layers of composite carbonaceous 185 grains, which Walsh (1992) compared to globular bacterial colonies or organic aggregates, however, the 186 biogenicity of these grains still needs to be further established (Trower and Lowe, 2016). In the following, 187 reported microbial mats and biofilms from the Middle Marker, the Buck Reef Chert, and Josefsdal Chert 188 will be described in more detail.

189

\section{$190 \quad$ 4.1.1 Middle Marker}

191 The 3.472 Ga Middle Marker (H1) at the base of the Hooggenoeg Formation represents the oldest, relatively 192 unmetamorphosed sedimentary unit of the BGB (Lanier and Lowe, 1982; Armstrong et al., 1990). It has a 193 thickness of 3 to $6 \mathrm{~m}$ and is composed of silicified komatiitic ash and fine layers of relatively pure 194 carbonaceous cherts that contain composite grains and carbonaceous wisps of proposed biogenic origin 195 (Lanier and Lowe, 1982; Walsh, 1992; Lowe, 1999; Walsh and Lowe, 1999). Deposition occurred likely 196 on a flat, tide- or wave influenced shelf in water depths of several 10s to 100 m (Byerly et al., 2019).

197 Fine, crinkly laminations, interbedded with the volcaniclastic sand- and siltstones of this unit, have been 198 interpreted as fossil microbial mats by Hickman-Lewis et al. (2018), mainly based on their carbonaceous 199 composition, micro-tufted morphology, sediment trapping and cohesive behavior, and the occurrence of 200 wisp-like structures, interpreted as erosional mat (Fig. 3A and B). The carbonaceous laminations occur in 201 packets of $200 \mu \mathrm{m}$ to $2.5 \mathrm{~mm}$ thickness, contain detrital quartz and volcanic grains, and generally have a 202 low surficial relief, which is described by the authors as micro-tufted (Fig. 3A and B). These crinkly, micro203 tufted structures $(<100 \mu \mathrm{m}$ in height) of proposed primary biogenic origin can be distinguished from pseudo204 tufted structures (up to $0.8 \mathrm{~mm}$ in height) that formed secondary as a result of plastic deformation triggered 205 by the settling of dense particles (Fig. 3C and D; Hickman-Lewis et al., 2018). The micro-tufted structures 
further

used

by

Hickman-Lewis

et

al.,

(2018)

to

tenta

207 were formed by anoxygenic phototrophs. However, it is hard to constrain the microbial metabolism relying

208 on mat morphology alone, especially if it is only of minor topographic relief and secondary deformation

209 structures are present. More valuable insights into the metabolism(s) of the Middle Marker mats could be

210 gained from the analysis of organic carbon isotopes, which would also help to further strengthen their

211 biogenicity.

212

\section{$213 \quad$ 4.1.2 Buck Reef Chert}

214 The 3.416 Ga Buck Reef Chert (K1) is a 250-400-m-thick unit of carbonaceous and ferruginous cherts at 215 the base of the Kromberg Formation, exposed continuously along nearly $50 \mathrm{~km}$ of strike in the west limb 216 of the Onverwacht Anticline (Kröner et al., 1991; Lowe and Worrell, 1999). A correlative section in the 217 east limb of the Onverwacht Anticline comprises three 10-25-m-thick chert units (Kc1, Kc2, Kc3), that are 218 interbedded with basalt flows (Walsh, 1992; Lowe and Byerly, 1999). The cherts are thought to be of 219 primary origin and likely precipitated from normal marine water, which was saturated with respect to 220 amorphous silica during the Archean (Lowe, 1999b; Knauth and Lowe, 2003; Tice and Lowe, 2006a) rather 221 than from hydrothermal fluids (de Wit et al., 1982; Westall et al., 2001). Sediments of the Buck Reef Chert 222 were deposited on subsiding open-marine volcanic platform and can be subdivided in three main 223 depositional facies (basal evaporitic, middle platform, and deep basin), which reflect deposition under 224 successively deeper-water conditions (Tice and Lowe, 2004). The silicified evaporites from the evaporitic 225 facies, were originally interpreted as remnants of nahcolite (Lowe and Worrell, 1999) but may represent 226 pseudomorphs after aragonite (Otálora et al., 2018). Fine anastomosing carbonaceous laminations (Fig. 4A227 F) and in places ripped up, plastically deformed rolled-up fragments (Fig. 5 A and B), occurring within 228 black bands in black-and-white banded cherts of the platform facies, were interpreted as remnants of 229 cohesive microbial mats (Walsh and Lowe, 1999; Tice and Lowe, 2004, 2006a, 2006b; Tice, 2009; Tice et 230 al., 2011). The mats were once thriving in shallow-water, photic zone paleoenvironments below fair231 weather wave base and show three distinct mat morphotypes: (1) alpha-type, fine carbonaceous laminations 232 that incorporate and loosely drape detrital grains underlying detrital grains and form silica-filled lenses (Fig. $2334 \mathrm{~A}$ and B); (2) beta-type, fine meshworks of filament-like strands ( $<5 \mu \mathrm{m}$ in diameter), which drape 234 underlying detrital grains (Fig. 4C and D); and (3) gamma-type, evenly spaced flat laminations that tightly 235 drape underlying sediments (Fig. 4E and F; Tice, 2009). The formation of different mat morphotypes is 236 thought to be primarily controlled by local variations in ambient light intensity and/or current energy. 237 Consequently, the first two morphotypes (alpha and beta) probably formed in shallower water, which is 238 also supported by their more complex morphology and association with coarser-grained sediments (Tice 239 2009). Bulk organic carbon isotope measurements of the carbonaceous laminations, with $\delta^{13} C_{\text {org }}$ values 
240

241

242

243

244

245

246

247

248

249

250

251

252

253

254

255

256

257

258

259

260

261

262

263

264

265

266

267

268

269

270

271

272

273

ranging between $-36.9 \%$ and $-20.1 \%$, and a mean of $-29.9 \%$ o $(n=19$, Tice and Lowe $2006 \mathrm{~b})$, serve as additional evidence for a biogenic origin of the mats, which were formed by photosynthetic microbes that most likely applied hydrogen-based carbon fixation (Tice and Lowe, 2004a, 2006a). Raman microspectroscopic analysis further revealed that the carbonaceous matter preserved in the Buck Reef Chert has experienced sub- to lower-greenschist facies temperatures, consistent with regional peak metamorphic temperatures, and thus confirming its syngenetic origin (Tice et al., 2004; van Zuilen et al., 2007). Overall, the microbial mats preserved in the Buck Reef Chert represent one of the best documented evidence for ancient life in the Onverwacht Group. Future work could focus more on micro-scale investigations, increase the spatial resolution of organic carbon isotope measurements, and try to acquire also nitrogen isotope values in order to learn more about the biogeochemical cycling of these elements by the mat-forming microbial communities.

\subsubsection{Josefsdal Chert}

The Josefsdal Chert comprises a 6-30-m-thick succession of silicified volcaniclastic rocks, located in a fault-bounded sliver, and is considered to be the lateral equivalent of the $3.334 \mathrm{Ga}$ Footbridge Chert (K3c; (Kröner et al., 1996; Lowe and Byerly, 1999) at the top of the Kromberg Formation (Hofmann and Bolhar, 2007; Westall et al., 2015). Sedimentary structures, such as ripple marks, planar- and cross-lamination indicate that deposition likely occurred in tidal, nearshore environments under the influence of hydrothermal activity, which is supported by REE patterns with positive Eu and Y anomalies and was likely driven by the circulation of silica-saturated seawater through cooling basaltic lavas that occur stratigraphically below the Josefsdal Chert (Hofmann and Harris, 2008; Westall et al., 2011, 2015, 2018). Cracks, only a few $\mu \mathrm{m}$ in width, occurring in structures interpreted as fossil biofilms from these deposits, were further used to infer periods of subaerial exposure, desiccation, and evaporation (Westall et al., 2001; 2006). Such cracks are, however, less suitable to reconstruct the depositional context, as they are only visible with the SEM (scanning electron microscope) and not in the outcrops. Altermann (2001) suggested that these cracks and the pseudomorphic evaporite minerals, as well as some putative rod-shaped microfossils (2-3.8 $\mathrm{mm}$ long and interpreted as remnants of sulphate-reducing bacteria) described by Westall et al. $(2001,2006)$ from these cherts, might represent sample preparation artefacts introduced during HF etching (Wacey, 2009). Moreover, the fact that the anions of the putative, often idiomorphic, evaporite crystals have been replaced by fluorine (Westall et al., 2006) further indicates that they could represent artefacts, especially as it has been shown that mineral artefacts such as fluorides and fluosilicates commonly form during HF etching (Karkhanis, 1977) and might mimic evaporitic minerals. A more promising candidate for life in these deposits are therefore the structures that are visible in petrographic 
thin section and resemble silicified biofilms and microbial mats (Fig 6 A-C). The microbial mat-like structures occur in banded black and white cherts as layered packets, 100-1000 $\mu \mathrm{m}$ thick, that are composed

276 of $\sim 10 \mu \mathrm{m}$ thin, wavy carbonaceous biofilms with incorporated fine-grained detrital volcanic clasts and 277 quartz grains (Westall et al., 2006; 2011; 2015). Torn and plastically deformed fragments of these biofilms 278 occur partially peeled of below and above distinct mat horizons, which is interpreted as evidence for 279 contemporaneous (lateral?) injection of hydrothermal fluids (Fig. 6D, Westall et al., 2015). A single biofilm 280 (1-4 $\mu \mathrm{m}$ thick) exposed on fresh fractured bedding surface has been extensively studied by Westall et al. 281 (2001, 2006, 2011; sample 96SA05) and SEM observations revealed the presence of multiple layers of 282 parallel filament-like structures with constant diameter of $0.25 \mu \mathrm{m}$, which are embedded in a granular to 283 smooth film interpreted as extracellular polymeric substance. Carbonaceous clots, $50-500 \mu \mathrm{m}$ in diameter 284 and interpreted as degraded remnants of chemosynthetic biomass, represent another proposed biosignature 285 from Josefsdal Chert (Westall et al., 2015), however their biogenicity still needs to be further established. 286 Two bulk organic carbon isotope measurements from the Josefsdal Chert show $\delta^{13} \mathrm{C}_{\text {org }}$ values of $-22.7 \%$ 287 (bulk sample, Westall, et al 2001) and -26.8\% (carbon-rich black layer, Westall et al., 2006). While in situ 288 measurements of the carbonaceous biofilms yield $\delta^{13} \mathrm{C}_{\text {org }}$ values of $-45 \%$ to $-13 \%$ and a single $\delta^{34} \mathrm{~S}$ value 289 of $-24 \%$ (Westall et al., 2015). These values support a biogenic origin of the biofilms/mats and were further 290 used to conclude that the latter were formed by anoxygenic photosynthesizers and sulphur reducing bacteria 291 (Westall et al. 2011, 2015). Future in situ isotope studies on the organic remains in these samples should 292 increase the amount of data points and aim to better document the analytical areas (see e.g. Williford et al. $2932013,2016)$ in order to spatially resolve the large range of $\delta^{13} C_{\text {org }}$ values, and to distinguish it from the 294 background signal of the carbonaceous cherts, which might differ significantly, as documented by Oehler 295 et al. (2017) for samples of the Buck Reef Chert that show $\delta^{13} C_{\text {org }}$ values ranging between $-47.1 \%$ and $296-24.0 \%$.

297

\section{$298 \quad 4.2$ Microfossils}

299 The positive identification of Archean microfossils is due to their often very simple morphology extremely 300 challenging, several well-established criteria exist (see Schopf, 2004; Brasier et al., 2006; Wacey, 2009), 301 while in situ carbon isotope analysis of individual microfossil candidates has become another required 302 method for the evaluation of their biogenicity in recent years (e.g. House et al., 2013; Lepot et al., 2013; 303 Williford et al., 2013, 2016). Putative microfossils in the carbonaceous cherts of the Onverwacht Group are 304 extremely rare. The first systematic analysis of Walsh (1992) and Walsh and Lowe (1999) revealed that 305 only 9 of more than 400 analyzed samples contained possible microfossils of filamentous, lenticular, and 306 spheroidal shapes. 


\subsubsection{Filamentous structures}

309 Filamentous microstructures of carbonaceous composition were identified in a single $2 \mathrm{~cm}$ thick black-and-

310 white banded chert layer in the upper Hooggenoeg Formation (Walsh and Lowe, 1985; Walsh 1992). These

311 tread-like or cylindrical, unbranched filaments are solid, $0.2-2.5 \mu \mathrm{m}$ in diameter, up to $200 \mu \mathrm{m}$ long and 312 occur associated with carbonaceous laminations interpreted as microbial mats. Although originally 313 classified as possible microfossils Walsh (2000) noted that they may have formed abiotically and could 314 thus represent simple mineral filaments (Wacey, 2009).

315 More convincingly biological filaments occur associated with fossil mats in several localities of the Buck 316 Reef Chert (K1 and K1c2; Byerly et al., 2019). The hollow cylindrical filaments, $1.2-1.4 \mu \mathrm{m}$ in diameter 317 and $10-150 \mu \mathrm{m}$ in length, are composed of carbonaceous matter and fine pyrite (Fig. 7A-C). They mostly 318 occur oriented subparallel to bedding or sometimes as interwoven, tangled clumps (Walsh and Lowe, 1985; 319 Walsh 1992). These hollow, sheath-like filaments are similar in size and shape to modern filamentous 320 bacteria and are of possible organic origin (Walsh 1992, Altermann, 2001), however, high-resolution 321 petrographic and detailed in situ carbon isotope analysis would be desirable to further support this 322 interpretation.

\subsubsection{Lenticular structures}

326 Lenticular structures (previously named "spindle-shaped" structures) represent a group of enigmatic 327 microfossils that are also well-known from the Pilbara Craton of Western Australia where their biogenicity 328 is well established (e.g. Sugitani et al., 2007, 2010, 2013, Oehler et al., 2009, 2017; House et al., 2013; 329 Kozawa et al., 2018). There, the lenticular objects occur individually or in groups or chains of several 330 individuals. Lense- or, disk-shaped microstructures, 30-60 $\mu \mathrm{m}$ in long axis, with hollow centers and 331 carbonaceous walls have been first documented in the BGB by Pflug $(1966,1967)$ and Pflug et al., (1969) 332 from cherts of the Fig Tree Group that were later assigned to the upper Onverwacht Group (Mendon 333 Formation, previously named Swartkoppie Formation, (Schopf, 1975; Lowe and Knauth, 1977)). The 334 structures gently taper towards the ends of their long axes, occur isolated or sometimes in groups of two or 335 more specimens (Fig. 8A-D), which are connected at their poles, and were interpreted as the remains of 336 thread-like bacterial colonies (Pflug, 1966, 1967). Walsh (1992) interpreted very similar lenticular 337 structures, 13-135 $\mu \mathrm{m}$ long and 4.5-61 $\mu \mathrm{m}$ wide, from detrital layers above the basal evaporitic facies of 338 the Buck Reef Chert (K1) as possible sheaths of colonies of bacterial cells or carbonaceous coatings around 339 former gypsum crystals (Fig. 8E-H). A biological origin of the structures is supported by in situ $\delta^{13} \mathrm{C}_{\text {org }}$ 340 analysis that revealed values ranging between $-39.3 \%$ to $-35.5 \%$, consistent with autotrophic carbon 341 fixation ( $\mathrm{n}=8$; Oehler et al., 2017). Based on their robust morphology, shallow water habitat and $\delta{ }^{13} \mathrm{C}_{\text {org }}$ 
342

343

344

345

346

347

348

349

350

351

352

353

354

355

356

357

358

359

360

361

362

363

364

365

366

367

368

369

370

371

372

373

374

375

values Oehler et al. (2017) proposed that the lenticular forms might represent microbes with a planktonic stage in their life cycle, making it to a very promising claim for microbial life in the BGB.

\subsubsection{Spheroidal structures}

Spheroidal microstructures of carbonaceous composition belong to a very common group of putative microfossils in the Onverwacht Group but the evaluation of their biogenicity is due to their simple morphology often very challenging.

Glikson et al. (2008) identified clusters of spheroidal, cell-like objects (2-10 $\mu \mathrm{m}$ in diameter) with granular walls from cherts of the Hooggenoeg Formation ( $\mathrm{H} 3 \mathrm{c}$ and $\mathrm{H} 5 \mathrm{c})$, which display features of possible cell wall degradation (Fig. 9A and B). The spheroids are comparable with the modern hyperthermophilic Methanocaldococcus jannaschii and were thus interpreted as remnants of chemosynthetic microbes once thriving in a seafloor hydrothermal system. This is a promising sign for life, but follow-up studies should also document the sedimentological context, perform analysis on more than two samples, and include in situ isotope measurements (Wacey et al., 2009). Large granular-walled spheroids and ellipsoids (10-84 $\mu \mathrm{m}$ in length; Fig. 9C and D) and clusters of thin-walled spheroids (4.5-12.8 $\mu \mathrm{m}$ in diameter; Fig. 9E and F) from the Buck Reef Chert were interpreted as probable microfossils of coccoidal bacteria or spores (Walsh, 1992). However, these simple spheres may be produced abiotically in various ways and were therefore reinterpreted as abiotic self-organized structures, such as spherulitic chert (Brasier et al., 2006). Kremer and Kazmierczak (2017) reported spheroidal microstructures, 3-12 $\mu \mathrm{m}$ in diameter, from the Buck Reef Chert (K1c2) and tentatively conclude that they may represent the variably degraded remains of coccoidal cyanobacteria (Fig. 9G and H). Although the cell-like objects occur in groups or clusters, preserved in black cherts with bulk $\delta^{13} \mathrm{C}_{\text {org }}$ values of $-26.5 \%$ and $-24.3 \%$ o $(n=2)$, their outer walls often have a more angular than rounded appearance, which resemble crystal terminations, thus making a biological origin less favorable (Hickman-Lewis, 2019). Alternatively, these objects might represent carbonaceous linings on replaced minerals or crystal rims (Brasier et al., 2006). Moreover, beyond morphological similarity, the positive identification of cyanobacteria and oxygenic photosynthesis hundreds of millions of years before most other evidence, requires independent geochemical evidence for the local presence of free oxygen, which is currently not available. Future studies should include nanoscale analysis of the putative cell walls and in situ isotope measurements.

Another occurrence of possible organic microspheres, 1- $4 \mu \mathrm{m}$ in diameter, has been described by Knoll and Barghoorn (1977) from the Msauli Chert (M1c; Mendon Formation, previously named Swartkoppie Formation (Lowe, 1999c)), which was deposited in shallow-water nearshore environments (Fig. 9I). These carbonaceous spheres occur as isolated or paired objects, are often flatten, wrinkled or folded, show a narrow unimodal size frequency distribution $(n=200)$, evidence of possible cell division, and were 
376

377

378

379

380

381

382

383

384

385

386

387

388

389

390

391

392

393

394

395

396

397

398

399

400

401

402

403

404

405

406

407

408

409 interpreted as the remains of primitive prokaryotes (Knoll and Barghoorn, 1977). However, without any geochemical analysis also these structures cannot be unambiguously identified as biological (Wacey, 2009).

\subsection{Stromatolites}

Compared to its Australian counterpart the currently known stromatolite occurrences in the BGB are very rare. Byerly et al. (1986) reported putative pseudocolumnar stromatolites that crop out for more than $10 \mathrm{~km}$ along strike in grey to black cherts assigned to member M2c of the $\sim 3.23$ Ga Mendon Formation (Walsh, 2004; Lowe and Byerly, 2015), which is interbedded with komatiitic lava flow deposits. [Note that these outcrops were initially assigned to the Fig Tree Group (Byerly et al., 1986), but are now thought to belong to the Mendon Formation in the upper Onverwacht Group (Lowe, 1994)]. The possible stromatolites occur in layers of $<1$ to $20 \mathrm{~cm}$ thickness and display variable morphologies, ranging between low-relief, asymmetrical, sometimes laterally-linked domes (1-3 cm wide and $0.5-3 \mathrm{~cm}$ high), rare pseudocolumns with bridging laminae (up to $10 \mathrm{~cm}$ height), and crinkly stratiform laminations (50-100 $\mu \mathrm{m}$ thick; Fig. 10A and B). Individual laminae are composed of minor amounts of primary carbonaceous matter and variable amounts of secondary, fine-grained, often idiomorphic tourmaline minerals (sometimes up to 50\%), which may have been derived through the hydrothermal remobilization of previously formed, boron-rich evaporites (Fig. 10C; Byerly and Palmer, 1991). Alternatively, the tourmaline mineralization could have been caused by heating and partial ocean evaporation related to a large asteroid impact recorded by spherule beds S5 and S8, which occur associated with some of the stromatolites (Lowe and Byerly, 2015). Conglomerates composed of laminated silica chips occur in the throughs between stromatolite domes and have been interpreted as fragments of eroded stromatolites or sinter crusts, likely deposited in the aftermath of a large impact (Fig. 10D). Similar stromatolite-crust chip conglomerates have also been reported from the Fig Tree Group (Sheba Formation) where they are overlain by spherule bed S5 (Lowe and Byerly, 2015, 2018). The stromatolitic structures were possibly formed by hyperthermophilic microbial communities in shallow-water depositional environments during periods of relative volcanic quiescence and likely experienced the profound effect of distant asteroid impacts (Byerly et al., 1986; Lowe and Byerly, 2018).

The widespread occurrence, morphological variability, and similarity to other fossil and modern stromatolites suggest a biogenic origin of these structures (Awramik, 1992). However, organic carbon isotope measurements, three-dimensional morphological investigations, a better documentation of the different morphotypes (Allwood et al., 2006), combined with high-resolution petrographic analysis, and a clear distinction from possibly abiogenic hot-spring silica crust precipitates (Lowe, 1994) would be desirable to further support this interpretation. 


\section{5. The $\sim 3.22$ Ga Moodies Group}

412 The ca. 3.22 Ga Moodies Group is the uppermost stratigraphic unit of the BGB and represents the world's 413 oldest well-preserved alluvial to shallow-marine tidal deposit. It consists of a up to $3.5 \mathrm{~km}$ thick succession 414 of quartz-rich sandstones with subordinate conglomerates, mudstones, siltstones, thin volcanic tuff beds, 415 minor banded iron formations and a basaltic lava, deposited in marine (deltaic, inter-, and subtidal) and 416 terrestrial (alluvial, fluvial, possibly aeolian) paleoenvironments (Hall, 1918; Visser, 1956; Anhaeusser, 417 1976; Eriksson, 1977, 1979, Heubeck and Lowe, 1994a, 1999; Simpson et al., 2012; Homann et al., 2015, 418 2018; Heubeck et al., 2016). The age of the Moodies Group is tightly constrained by Uranium-lead dating 419 of single-zircons from several dacitic tuffs and rare felsic dykes, which indicate that deposition began about $4203.223 \pm 1 \mathrm{Ga}$ and had ended by about 3.219 $\pm 9 \mathrm{Ga}$ (De Ronde and Kamo, 2000; Heubeck et al., 2013). 421 Moodies strata north of the Inyoka Fault are preserved in several, commonly northward-overturned 422 synclines that are tectonically separated by major faults (Fig. 2). These deposits not only contain a large variety of well- preserved sedimentary structures, they also offer a high-resolution archive of Paleoarchean surface and sedimentation processes, as well as a unique window into a widespread, diverse and well adapted microbial ecosystem. Reported biosignatures from the Moodies Group include intertidal and fluvial microbial mats, silicified remnants of cavity-dwelling microorganisms (coelobionts), and large organicwalled microfossils (acritarchs), as detailed below.

428

429

\subsection{Microbial mats}

Fossil microbial mats in the Moodies Group have been identified so far in intertidal deposits of the Saddleback Syncline and in alluvial-fluvial deposits of the Dycedale Syncline (Fig. 11A-C).

In the Saddleback Syncline the mats are preserved as carbonaceous, crinkly laminations (0.5-1 mm thick), interbedded with medium- to coarse-grained sandstones, and associated with desiccation cracks (Fig. 12A) They represent the oldest known examples of siliciclastic tidal mats in the geological record (Noffke et al., 2006; Heubeck, 2009; Gamper et al., 2012; Homann et al., 2015). These mats draped and stabilized horizontally laminated and rippled sandstones, and show an enrichment in fine-grained quartz and feldspar, as well as heavy mineral grains (zircon and rutile or anatase), likely caused by microbial baffling and trapping, which is a commonly observed in epibenthic microbial mats (Gerdes et al., 2000). Microbial-matassociated structures such as eroded mat fragments (mat chips), macroscopic tufts, shrinkage cracks, silicified gas domes and lenses, and subvertical fluid-escape structures are indicative for a former cohesive consistency and very common features in these deposits supporting the biogenic origin of the mats (Fig. 12B-D; Heubeck, 2009; Homann et al., 2015, 2016, 2018), while microbial wrinkle structures previously reported by Noffke et al. (2006) have not been observed in any of the follow-up studies. A detailed study 
444

of the sedimentological and paleoenvironmental context of these fossil mats revealed that they are laterally

445 traceable for $\sim 15 \mathrm{~km}$ in a $\sim 1000 \mathrm{~m}$-thick succession in the lower part of the Saddleback Syncline and show

446 distinct morphological adaptations to different hydrodynamic settings: (1) planar-type in coastal floodplain,

447 (2) wavy-type in intertidal, and (3) tufted-type in upper inter- to supratidal facies (Homann et al., 2015).

448 Such facies dependent changes in the prevalent mat morphotypes are to be expected in a dynamic, tidally-

449 influenced coastal environment and serve as an additional biogenicity indicator (Allwood et al., 2006;

450 Brasier et al., 2006). Moreover, the widespread occurrence of these fossil mats is consistent with a primary, 451 microbially mediated, cohesive erosion-resistant relief on the paleosurface that was locally deformed by 452 migrating gases and fluids, and in places eroded and incorporated in mat-chip conglomerates.

453 Based on the restriction of the mats to shallow-water, photic zone environments and their apparent absence 454 in subtidal settings, it is very likely that they were formed by phototrophic microbial communities (Noffke 455 et al., 2006; Heubeck, 2009, Homann et al., 2015). In fact, the Moodies microbial mats show some striking 456 morphological similarities to modern cyanobacterial mats e.g. from Bahar Alouane, Tunisia (Fig. 12A-D; 457 Gerdes et al., 2000; Gerdes, 2007), Shark Bay, Australia (Jahnert and Collins, 2013), 2013), Texas Gulf 458 Coast, USA (Bose and Chafetz, 2009), and the Red Sea of Saudi Arabia (Taj et al., 2014). Especially the 459 occurrence of mats with macroscopic, 0.3 -to-1 cm-high tufts that closely resemble tufted mats build by 460 filamentous cyanobacteria (Fig. 12C), led to the conclusion that the tufted mats of the Moodies Group were 461 perhaps build by ancestral cyanobacteria (Homann et al., 2015). Even tough, no geochemical data 462 supporting the local presence of free oxygen (and thus oxygenic photosynthesis) at 3.22 Ga have been found 463 so far in the Moodies Group, fossil evidence indicative for ancient gas production, accumulation, and 464 migration is plentiful in the near vicinity of the mats. Now chert-filled cavities in the interior of some tufts 465 likely represent silicified gas bubbles that were trapped within the mat fabric, which is a common feature 466 in cyanobacterial mats that produce oxygen-rich bubbles with strikingly similar morphologies (Fig. 12C; 467 Bosak et al., 2010; Homann et al., 2015). Other types of silicified cavities include domes and bedding 468 parallel lenses beneath the fossil mats that either formed through accumulation of gases produced by 469 metabolic activity, due to the decay of organic matter, or alternatively by tidal-driven hydraulic pumping 470 of the ambient air trapped in pore space (Figs. 12D and 14; Homann et al., 2016). Some of these cavities 471 where also inhabited by microbial communities (see below in 5.2).

472 Besides the main mat occurrence in the tidal marine deposits of the Saddleback Syncline, fossil microbial 473 mats also have been identified in the Dycedale Syncline (Homann et al., 2018), where a large variety of 474 sedimentary structures indicates that this succession records a transition from alluvial-fluvial (terrestrial) to 475 tide-influenced marine sedimentation (Heubeck and Lowe, 1994; Eriksson et al., 2006; Heubeck et al., 476 2016). These terrestrial mats occur confined to fluvial deposits at the base of a transgressive sequence that 477 gradually deepens upward through deltaic, and medium-energy tidal, into subtidal siliciclastic deposits. 
478 They are in interbedded with gravely sandstones, drape conglomerate beds, are plastically deformed by 10 479 to 50-cm-high fluid-escape structures, and commonly experienced periods of subaerial exposure and 480 desiccation evidenced by associated desiccation cracks (Fig. 13A and B). The terrestrial microbial mats of 481 the Dycedale Syncline currently represent the oldest direct fossil trace for life on land (Homann et al., 482 2018). Overgrowth rims in pyrites from Moodies Group paleosols show signs of biogenic sulfur 483 fractionation $\left(\delta^{34} \mathrm{~S}_{\mathrm{VCDT}}\right.$ values between $-20 \%$ and $-24.5 \%$ ) and provide additional geochemical evidence 484 for the presence of a Paleoarchean terrestrial biosphere (Nabhan et al., 2016a, b). Compared to the marine 485 mats the carbonaceous laminae of terrestrial mats are similarly well preserved, but with up to $4 \mathrm{~mm}$ of 486 preserved thickness often thicker than their marine counterparts (Fig. 11A and B; Fig. 13C). They are 487 composed of a dense meshwork of interwoven filament-like microstructures that envelop fine-grained 488 detrital particles whose long axes are preferentially aligned parallel to bedding (Fig. 13D and E; Homann 489 et al., 2018). Individual carbonaceous filamentous structures are 1-3 $\mu \mathrm{m}$ in diameter and resemble modern 490 biofilm-forming, filamentous microorganisms. In places, a notable enrichment of tourmaline minerals can 491 be observed in the mat fabric, which has also been reported from the stromatolitic laminae of the Mendon 492 Formation (Byerly et al., 1986; Byerly and Palmer, 1991) and might be driven by evaporitic processes, but 493 certainly demands further investigations. Raman spectroscopic analyses confirmed that both the terrestrial 494 and marine mats are composed of organic carbon that has experienced similar peak temperatures of $\sim 365^{\circ} \mathrm{C}$, 495 consistent with the metamorphic grade of the Moodies Group (Xie et al., 1997; Tice et al., 2004) and thus 496 demonstrating their synsedimentary origin and biogenicity (Homann et al., 2018). A detailed study of 497 Homann et al. (2018) documented a significant difference in the biogeochemical cycling of carbon and 498 nitrogen in terrestrial and marine mats. The preserved organic matter in the terrestrial mats shows $\delta^{13} \mathrm{C}_{\text {org }}$ 499 values ranging between $-23.6 \%$ and $-17.9 \%$ (mean $=-21.2 \% ; \mathrm{n}=36)$ and $\delta^{15} \mathrm{~N}$ values between $+1.9 \%$ 500 and $+5.6 \%$ (mean $=+4.3 \% ; \mathrm{n}=10$ ), in contrast to marine mats that show $\delta^{13} \mathrm{C}_{\mathrm{org}}$ values ranging between $501-33.9 \%$ and $-21.3 \%$ o $($ mean $=-27.4 \% ; n=30)$ and $\delta^{15} \mathrm{~N}$ values between $-0.7 \%$ and $+3.1 \%$ o $($ mean $=$ $502+1.8 \% ; \mathrm{n}=10$ ). This $\delta^{13} \mathrm{C}_{\text {org }}$ composition of the terrestrial mats is consistent with autotrophic carbon 503 fixation through the Calvin-Benson cycle, while $\delta^{13} \mathrm{C}_{\text {org }}$ values of the marine mats are best explained by 504 carbon fixation via the Wood-Ljungdahl pathway, which includes acetogenic bacteria, methanogens and 505 sulfate reducers. The observed trend in the Moodies Group microbial mats with $\delta^{15} \mathrm{~N}$ values from as low as $506-1 \%$ (marine) to up to $+5 \%$ o (terrestrial) likely reflects increasing fixed-nitrogen (i.e., nitrate, nitrite or 507 ammonium) and conversion to $\mathrm{N}_{2} \mathrm{O} / \mathrm{N}_{2}$ in the terrestrial habitats, which further suggests that they possessed 508 a fundamentally different respiratory community at depth in the mat, one that must have been sufficiently 509 oxygenated for aerobic Nitrogen cycling (Ader et al., 2016; Stüeken et al., 2016). Alternatively, the 510 contrasting nitrogen isotope compositions between terrestrial and marine settings could be related to a 
511 constant flux of atmospherically-fixed nitrogen on the early land surface that was probably too diffuse to 512 be a significant source of fixed nitrogen to the marine biosphere (Homann et al., 2018).

513

\section{$514 \quad 5.2$ Cavity-dwelling life}

515 Lens-shaped, laterally tapering cavities, up to tens of centimeters in width and $<0.5 \mathrm{~cm}$ in height, frequently 516 occur beneath fossil microbial mat in intertidal deposits of the Saddleback Syncline (Fig. 14A; Homann et 517 al., 2016). The silicified cavities resemble gas-filled, fenestral hollows in modern coastal environments that 518 commonly form beneath cohesive, impermeable microbial mats and mat-bound sediments (Gerdes et al., 519 2000; Schieber et al., 2007). Due to the presence of carbonaceous laminations and wisps these chert lenses 520 were initially interpreted as partially silicified epibenthic microstromatolites or thick mucilagous mats 521 (Heubeck 2009; Gamper et al., 2011), however, Homann et al. (2016) reported the additional presence of 522 pendant columnar microstromatolites attached to the ceilings of former cavities and concluded that they 523 must have accreted downwards in an open void space of synsedimentary origin (Fig. 14B-E). This gravity524 oriented geometry and the downward-accretionary growth habit is well known from cavity-dwelling 525 microorganisms (coelobionts; Kobluk and James, 1979; Jakubowicz et al., 2014), which have also been 526 reported from synsedimentary cavities beneath microbial mats in sandstones of the Neoarchean Fortescue 527 Group in Australia (Rasmussen et al., 2009). In places, sub-circular to ovoid-shaped fenestrae $(\sim 500 \mu \mathrm{m}$ in 528 diameter) that resemble trapped gas bubbles occur wedged between the carbonaceous laminae (Fig. 14C). 529 SEM observations of the cavity-filling cherts reveal the presence of: (1) polygonal structures after HF 530 etching for 28 days, interpreted as remnants of extracellular polymeric substance (EPS, Gamper et al., 531 2012), and (2) a meshwork of interwoven filamentous molds of likely biogenic origin that is completely 532 embedded in the chert (Fig. 14F; unetched samples, Homann et al., 2016). The non-branching filaments $533(0.3-0.5 \mu \mathrm{m}$ in diameter, $\mathrm{n}=180)$ display a subdivision in regularly spaced, $\sim 2-\mu \mathrm{m}$ - long, rod-shaped 534 segments and have a tubular morphology in cross section (Fig. 14G and H). Bulk carbon isotope 535 measurements of the chert-bearing sandstones show $\delta^{13} \mathrm{C}_{\text {org }}$ values between $-23.8 \%$ and $-14.1 \%$ o $(\mathrm{mean}=$ $536-20.5 \%, \mathrm{n}=15$; Gamper et al., 2012), however, in situ measurements of the carbonaceous laminae within 537 the chert-cemented cavities yield $\delta^{13} \mathrm{C}_{\text {org }}$ values ranging between $-32.3 \%$ and $-21.3 \%$ (mean $=-26.5 \%$; $\mathrm{n}$ $538=12$ ) that are probably more representative. These values are consistent with a purely chemotrophic or a 539 photosynthetic community of coelobionts and support the biogenicity of the oldest evidence for cavity540 dwelling life on Earth (Homann et al., 2016). Moreover, these findings support the view the cavities were 541 among the first ecological niches to have been occupied by early microbial communities.

542

543

$544 \quad 5.3$ Organic-walled microfossils 
545 Carbonaceous spheroidal microstructures, $31-300 \mu \mathrm{m}$ in diameter (mean=122 $\mu \mathrm{m}, \mathrm{n}=98$ ), have been

546 identified in bedded siltstones and shales from underground drill cores that were assigned to the Clutha

547 Formation and drilled 600m below the surface in the Agnes gold mine, Moodies Hills Block (Javaux et al.,

548 2010). The carbonaceous structures are visible in petrographic thin sections and resistant to extraction via

549 acid maceration (Fig. 15A-D). They show wrinkled and folded textures, a $\sim 160$-nm-thick wall with a

550 homogenous ultrastructure and were interpreted as flattened, hollow, and partially degraded, organic-walled

551 vesicles with preserved cell lumen (Fig. 15E-F; Javaux et al., 2010). Bulk carbon isotopes measurements

552 show a large spread in $\delta^{13} \mathrm{C}_{\text {org }}$ values ranging between-16.4\% and $-28.3 \%$, with an average of $-22.4 \%$

$553(\mathrm{n}=22)$, but no difference in the $\delta^{13} \mathrm{C}_{\text {org }}$ values between samples with and without microfossils has been

554 observed. Consequently, such bulk measurements might not be very useful in constraining the biogenicity

555 of the microstructures, however their carbonaceous composition and syngenetic origin is supported by

556 Raman microspectroscopy. Based on their taphonomy and for the Paleoarchean uncommonly large size,

557 Javaux et al. (2010) and Buick (2010). Javaux et al. (2010) concluded that the organic-walled microfossils

558 might either represent remnants of extinct prokaryotes, colonial envelopes of cyanobacteria, or even

559 eukaryotes. To unravel the biological affinity of these acritarchs remains the task for future investigations,

560 which should ideally also aim to identify the microstructures in outcrop samples in order to further constrain

561 their habitat and explore their possible relationship with the widespread, shallow-water microbial mats of

562 the Moodies Group.

563

\section{6. Discussion}

565

566 6.1 Evidence of Paleoarchean life in the BGB and comparison to the PGBs

567 Traces of ancient life in the BGB occur mainly confined to bedded, carbonaceous cherts of the Onverwacht

568 Group and the siliciclastic deposits of the Moodies Group. Preserved biosignatures in these deposits include 569 putative microfossils of filamentous, spheroidal, and lenticular shape, stromatolites, and microbial mats.

570 Filamentous microfossils occur very rarely in cherts of the Onverwacht Group but their biogenicity remains 571 equivocal (Walsh and Lowe, 1985; Walsh 1992, 2010). The rod-shaped filamentous molds preserved in 572 early silicified, syndepositional cavities of the Moodies Group resemble in shape and size microbial 573 filaments and also their depositional context, beneath intertidal microbial mats, supports a biogenic origin 574 (Homann et al., 2016). Spheroidal microstructures with carbonaceous walls, resembling coccoidal cells, 575 belong to the most common group of putative microfossils in the Onverwacht Group but the assessment of 576 their biogenicity is in most cases extremely challenging due to their simple, often symmetrical morphology 577 that can be easily generated abiogenetically in form of e.g. fluid inclusions, vesicles, and spheroidal 578 crystallites (Schopf and Walther 1983; Brasier et al., 2006). Solely, the spheroidal, cell-like objects reported 
by Glikson et al. (2008) from the Hooggenoeg Formation and the large, organic-walled spheroids described 580 by Javaux et al. (2010) from the Moodies Group have a well-established biogenicity. However, the 581 biological affinity of the latter and the reason for their unusually large size currently remains unknown. 582 Lenticular structures preserved in the Buck Reef Chert (Walsh 1992; Oehler et al., 2017) and probably also 583 other cherts of the upper Onverwacht Group (Pflug 1966, 1967; Pflug et al., 1969) belong to the earliest 584 reported and currently best studied microfossils in the BGB. Remains of these, likely planktonic, 585 microorganisms have also been reported from the 3.45 Ga Strelley Pool Formation and the $\sim 3$ Ga Farrel 586 Quartzite in the Pilbara Craton where their biogenicity is reasonably well established (e.g. Oehler et al., 587 2009, 2017; Sugitani et al. 2007, 2010, 2013; House et al., 2013; Kozawa et al., 2018). The morphologically 588 similar specimens from Australia occur in the same depositional context and show strikingly similar mean $589 \delta^{13} \mathrm{C}_{\text {org }}$ values (-37.0\% and $\left.-36.1 \%\right)$ in comparison to their South African counterparts with a mean $\delta^{13} \mathrm{C}_{\text {org }}$ 590 value of $-37.3 \%$ (Oehler et al., 2017). Abiogenic models for the formation of similar-looking structures 591 derived from reworked vesicular volcanic glass exists (Wacey et al., 2018a, 2018b), however these pseudo592 fossils do not resemble the same morphological and microstructural complexity (Alleon et al., 2018; 593 Kozawa et al., 2018). Nevertheless, the occurrence of such pseudo-fossil examples highlights again the 594 paramount importance of detailed micro- and nanoscale analysis in the evaluation of the biogenicity of 595 putative microfossils. Additionally, future studies of microfossil-bearing cherts of the Onverwacht Group 596 should always be accompanied by detailed analysis of the stratigraphic context and depositional facies, in 597 combination with in in situ geochemical analysis of the microfossils themselves and their encasing mineral 598 matrix.

599 Stromatolites, generally considered as the most ancient macroscopically-visible traces for life on Earth, are 600 surprisingly rare and currently not as well documented in the BGB in comparison to the PGBs, where the 601 oldest unequivocal biogenic examples occur preserved in the 3.45 Ga Strelley Pool Formation (Allwood, 602 et al 2006) and possibly also in the 3.48 Ga Dresser Formation (Fig. 16; Walter et al., 1980; Van 603 Kranendonk et al., 2008). However, the often morphological very simple, laminated, domal to conical 604 structures of Archean stromatolites can be easily confused with secondary abiogenic structures, especially 605 in the absence of indicative microfossils. A recent study of Allwood et al. (2018), highlighting the 606 importance of morphological analysis in combination with geochemistry at appropriate scales, serves as a 607 cautionary tale and strongly questions the biogenicity of previously reported putative stromatolites from $6083.7 \mathrm{Ga}$ old metacarbonate rocks of Greenland (Nutman et al., 2016). Compared to the greenstone belts in 609 the Pilbara region, the documented deposit of the BGB contain only minor evidence of early carbonate 610 environments, which is probably related to the predominance of volcanic and clastic deposition in 611 combination with high sedimentation rates that made the conditions for stromatolite formation less 612 favorable. 
613 The most widespread, pervasive, and probably also oldest trace of ancient life in the BGB are the remnants

614 of shallow-water microbial mats and biofilms. Mat-like laminations occur in almost all black-and-white615 banded, carbonaceous cherts of the Onverwacht Group (Walsh 1992), but only the examples reported from 616 the 3.472 Ga Middle Marker (Hickman-Lewis, et al, 2018), the 3.416 Ga Buck Reef Chert (Walsh and 617 Lowe, 1999; Tice and Lowe, 2004a, 2006a, b; Tice, 2009; Tice et al., 2011), and the 3.334 Ga Josefsdal 618 Chert (Westall et al., 2011, 2006, 2011, 2015) are reasonably well studied to support their biogenic origin. 619 Especially the mats and microfossils preserved in the up to 400-m-thick Buck Reef Chert represent a 620 particularly widespread ( $\sim 50 \mathrm{~km}$ along strike), well-preserved and -documented record of the Paleoarchean 621 life. Besides the necessity to carefully reinvestigate more potentially microfossil- and mat-bearing 622 carbonaceous cherts in the BGB it is also crucial to further support the already existing claims for early life 623 from these units with more detailed geochemical analysis such as e.g. carbon, nitrogen, and sulphur isotope 624 data. The microbial mats preserved in the tidal and fluvial sandstones and conglomerates of the $3.22 \mathrm{Ga}$ 625 Moodies Group are unique and currently not known from equivalent deposits from Austalia (Fig. 16; 626 Noffke et al., 2006; Heubeck, 2009; Gamper et al., 2012; Homann et al., 2015, 2018). The quality of 627 preservation of the delicate carbonaceous mat laminae, distinct morphotypes, and mat-associated cavities 628 in these coarse-grained and gravely siliciclastic deposits is truly exceptional and implies a rapid fossilization 629 driven by early diagenetic silicification of the sediments (Heubeck 2009; Homann et al., 2015). The 630 observed difference in the biogeochemical cycling of carbon and nitrogen in tidal marine and fluvial 631 microbial mats from the Moodies Group (Homann et al., 2018) has demonstrated the potential of detailed 632 geochemical analysis, which can give valuable insights in the different carbon fixation pathways and 633 ultimately helps to constrain the metabolism(s) of the mat-building microbial communities and should 634 consequently also be applied more extensively to the mats preserved in the Onverwacht Group. 635

\section{$636 \quad 6.2$ Habitats and paleoecology}

637 Evidence for Paleoarchean life in the BGB have been reported from a wide range of paleoenvironments 638 including shallow marine (e.g. Byerly et al., 1986; Tice and Lowe, 2004a; Heubeck 2009; Homann et al., 639 2015), fluvial (Homann et al., 2018), hydrothermal (Glikson et al., 2008; Westall et al., 2015), and possibly 640 planktonic settings (Walsh 1992; Oehler et al., 2017), as well as from cryptic cavities in the shallow 641 subsurface of intertidal deposits (Homann et al., 2016). Due to the general restriction of microbial mats to 642 shallow-water, photic zone paleoenvironments of the BGB, the common notion is that they were at least in 643 part composed of photosynthetic microbial communities and already had a high level of UV radiation 644 tolerance, while the microorganisms thriving in a hydrothermal context or in cavities were likely dominated 645 by chemotrophic communities. Nearly all of these early microbial communities must have been severely 646 affected by distant impacts of large asteroids (20 to $50 \mathrm{~km}$ in diameter), which occurred between $3.470 \mathrm{Ga}$ 
and 3.225 Ga and are recorded in the BGB deposits by eight known ejecta layers (Fig. 2; Lowe and Byerly, 648 1986, 2018; Lowe et al., 1989). Besides impact-generated tsunamis it has been proposed that some of these 649 catastrophic events might have been large enough to cause partial boiling and sterilization of the oceans 650 and possibly triggered mass extinctions of low-temperature microbes, including most photosynthetic 651 microorganisms (Sleep et al., 1989; Lowe and Byerly, 2015). The question of how exactly early life 652 managed to survive these events or if the global ecosystem got entirely destroyed and biogenesis was reset 653 currently remains open.

654 The Moodies Group ecosystem was particularly diverse, advanced, and well-adapted and includes large 655 spheroidal microfossils, Earth's earliest evidence of cavity-dwelling microbes (coelobionts), widespread 656 intertidal tufted microbial mats, laterally traceable for $15 \mathrm{~km}$ in a $\sim 1000 \mathrm{~m}$-thick succession, as well as 657 erosion-resistant fluvial microbial mats. The latter represent the oldest known direct fossil evidence for 658 terrestrial life on the continental surface and are $\sim 500$ Ma older than $\sim 2.7$ Ga old fluvio-lacustrine 659 stromatolites and coelobionts preserved in the Fortescue Group (Tumbiana and Hardey Formation, 660 Australia; Buick, 1992; Awramik and Buchheim, 2009; Rasmussen et al., 2009; Coffey et al., 2013) and 661 fluvial stromatolites documented in the Ventersdorp Supergroup (South Africa; Buck, 1980). Based on the 662 apparent morphological similarities between the shallow-marine microbial mats of the Moodies Group and 663 modern cyanobacterial mats such as e.g. macroscopic tufts, evidence for gas production and accumulation 664 in bubbles and domes, and their widespread occurrence and presumably fast growth rate, it has been 665 proposed that they were perhaps build by ancestral cyanobacteria (Homann et al., 2015). A recent molecular 666 clock study by Cardona et al. (2018) supports this interpretation and suggest that a primordial photosystem 667 capable of oxidizing water to oxygen could have formed before the most recent common ancestor of 668 cyanobacteria. Additionally, also the unusually large size of the organic-walled microfossils reported by 669 Javaux et al. (2010) indirectly suggests the requirement and the availability of oxygen at $3.22 \mathrm{Ga}$, although 670 no unequivocal geochemical signs for the local presence of free oxygen have been found so far in the 671 Moodies Group.

672

\section{7. Conclusions}

674 The deposits of the Barberton Greenstone Belt host a large variety of convincing macro- and microscopic, 675 as well as geochemical evidence for early microbial life. It was predominantly thriving in shallow marine 676 environments in the photic zone but started to spread out to colonize fluvial habitats in emerged continental 677 surface environments and also occupied the first ecological niches, such as subsurface cavities. Traces of 678 ancient life in the BGB occur scattered throughout the entire stratigraphy confined to carbonaceous cherts 679 of the Onverwacht Group and siliciclastic deposits of the Moodies Group. However, their identification is 680 sometimes solely based on morphological attributes and not always accompanied by detailed and systematic 
geochemical analysis at appropriate scales, which should be improved in future investigations. Due to their 682 wealth of remarkably preserved microbial mats and microfossils, consistent lateral exposure for several 683 tens of kilometers and thick stratigraphy, especially the deposits of the 3.416 Ga Buck Reef Chert and the 684 sandstones of the 3.22 Ga Moodies Group represent a unique window into a diverse Paleoarchean 685 biosphere.

686 Based on its universal and outstanding geological and paleobiological value the Barberton-Makhonjwa 687 Mountains were inscribed in the UNESCO World Heritage Site register in 2018, which will ultimately help 688 to protect these exceptional outcrops for future studies of Earth's early evolution.

689

690

691

692

693

694

695

696

697

698

699

700

701

702

703

704

705

706

707

708

709

710

711

712

713

714

\section{Acknowledgements}

This work was greatly supported by LabexMER ANR-10-LABX-19 and Prestige COFUND-GA-2013609102 to M.H. Amongst many others, the author would especially like to thank Maud Walsh, Gary Byerly, Don Lowe, Christoph Heubeck, Dorothy Oehler, Wlady Altermann, and Andrew Knoll for their helpful comments. I am also indebted to Stefan Lalonde and Claire Earlie for useful discussions and comments on an earlier version of the manuscript.

\section{References}

Ader, M., Thomazo, C., Sansjofre, P., Busigny, V., Papineau, D., Laffont, R., Cartigny, P., Halverson, G.P., 2016. Interpretation of the nitrogen isotopic composition of Precambrian sedimentary rocks: Assumptions and perspectives. Chem. Geol. 429, 93-110. https://doi.org/10.1016/j.chemgeo.2016.02.010

Alleon, J., Bernard, S., Le Guillou, C., Beyssac, O., Sugitani, K., Robert, F., 2018. Chemical nature of the 3.4 Ga Strelley Pool microfossils. Geochemical Perspect. Lett. 37-42. https://doi.org/10.7185/geochemlet.1817

Allwood, A.C., Rosing, M.T., Flannery, D.T., Hurowitz, J.A., Heirwegh, C.M., 2018. Reassessing evidence of life in 3,700-million-year-old rocks of Greenland. Nature. https://doi.org/10.1038/s41586-018-0610-4

Allwood, A.C., Walter, M.R., Kamber, B.S., Marshall, C.P., Burch, I.W., 2006. Stromatolite reef from the Early Archaean era of Australia. Nature 441, 714-718. https://doi.org/10.1038/nature04764

Altermann, W., 2001. The oldest fossils of Africa - a brief reappraisal of reports from the Archean. J. 


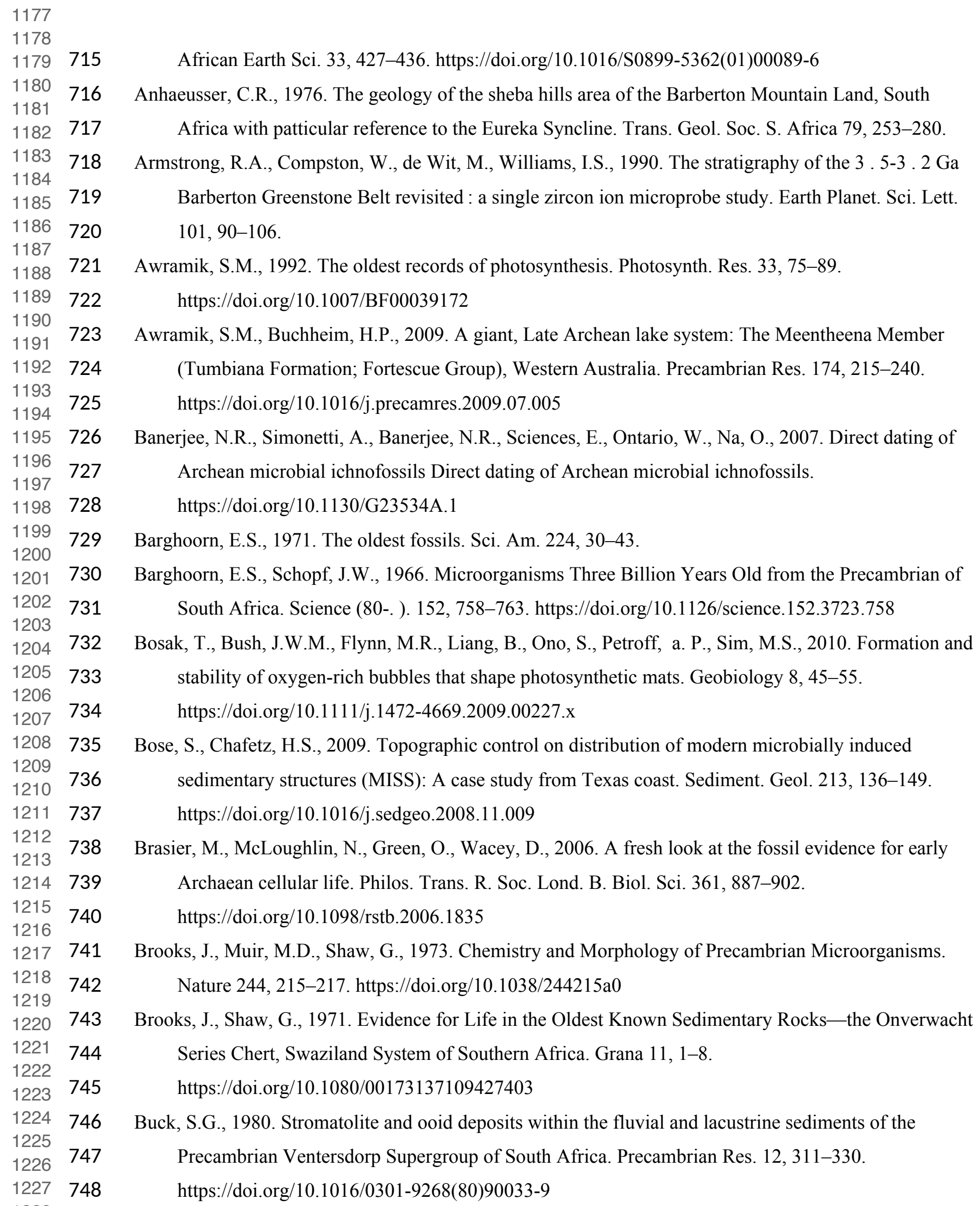

715

716

717

718

719

720

721

722

723

724

725

726

727

728

729

730

731

732

733

734

735

736

737

738

739

740

741

742

743

744

745

746

747

748

African Earth Sci. 33, 427-436. https://doi.org/10.1016/S0899-5362(01)00089-6

Anhaeusser, C.R., 1976. The geology of the sheba hills area of the Barberton Mountain Land, South Africa with patticular reference to the Eureka Syncline. Trans. Geol. Soc. S. Africa 79, 253-280.

Armstrong, R.A., Compston, W., de Wit, M., Williams, I.S., 1990. The stratigraphy of the 3 . 5-3 . 2 Ga Barberton Greenstone Belt revisited : a single zircon ion microprobe study. Earth Planet. Sci. Lett. $101,90-106$.

Awramik, S.M., 1992. The oldest records of photosynthesis. Photosynth. Res. 33, 75-89. https://doi.org/10.1007/BF00039172

Awramik, S.M., Buchheim, H.P., 2009. A giant, Late Archean lake system: The Meentheena Member (Tumbiana Formation; Fortescue Group), Western Australia. Precambrian Res. 174, 215-240. https://doi.org/10.1016/j.precamres.2009.07.005

Banerjee, N.R., Simonetti, A., Banerjee, N.R., Sciences, E., Ontario, W., Na, O., 2007. Direct dating of Archean microbial ichnofossils Direct dating of Archean microbial ichnofossils. https://doi.org/10.1130/G23534A.1

Barghoorn, E.S., 1971. The oldest fossils. Sci. Am. 224, 30-43.

Barghoorn, E.S., Schopf, J.W., 1966. Microorganisms Three Billion Years Old from the Precambrian of South Africa. Science (80-. ). 152, 758-763. https://doi.org/10.1126/science.152.3723.758

Bosak, T., Bush, J.W.M., Flynn, M.R., Liang, B., Ono, S., Petroff, a. P., Sim, M.S., 2010. Formation and stability of oxygen-rich bubbles that shape photosynthetic mats. Geobiology 8, 45-55. https://doi.org/10.1111/j.1472-4669.2009.00227.x

Bose, S., Chafetz, H.S., 2009. Topographic control on distribution of modern microbially induced sedimentary structures (MISS): A case study from Texas coast. Sediment. Geol. 213, 136-149. https://doi.org/10.1016/j.sedgeo.2008.11.009

Brasier, M., McLoughlin, N., Green, O., Wacey, D., 2006. A fresh look at the fossil evidence for early Archaean cellular life. Philos. Trans. R. Soc. Lond. B. Biol. Sci. 361, 887-902. https://doi.org/10.1098/rstb.2006.1835

Brooks, J., Muir, M.D., Shaw, G., 1973. Chemistry and Morphology of Precambrian Microorganisms. Nature 244, 215-217. https://doi.org/10.1038/244215a0

Brooks, J., Shaw, G., 1971. Evidence for Life in the Oldest Known Sedimentary Rocks- the Onverwacht Series Chert, Swaziland System of Southern Africa. Grana 11, 1-8. https://doi.org/10.1080/00173137109427403

Buck, S.G., 1980. Stromatolite and ooid deposits within the fluvial and lacustrine sediments of the Precambrian Ventersdorp Supergroup of South Africa. Precambrian Res. 12, 311-330. https://doi.org/10.1016/0301-9268(80)90033-9 
Buick, R., 2010. Early life: Ancient acritarchs. Nature 463, 885-886. https://doi.org/10.1038/463885a

Buick, R., 1992. The antiquity of oxygenic photosynthesis: evidence from stromatolites in sulphatedeficient Archaean lakes. Science (80-. ). 255, 74-77. https://doi.org/10.1126/science.11536492

Byerly, G.R., 1999. Komatiites of the Mendon Formation: Late-stage ultramafic volcanism in the Barberton Greenstone Belt, in: Lowe, D.R., Byerly, G.R. (Eds.), Geologic Evolution of the Barberton Greenstone Belt, South Africa. Geological Society of America, p. 0. https://doi.org/10.1130/0-8137-2329-9.189

Byerly, G.R., Lowe, D.R., Heubeck, C., 2019. Geologic Evolution of the Barberton Greenstone Belt-A Unique Record of Crustal Development, Surface Processes, and Early Life 3.55-3.20 Ga, in: Earth's Oldest Rocks. Elsevier, pp. 569-613. https://doi.org/10.1016/B978-0-444-63901-1.00024-1

Byerly, G.R., Lowe, D.R., Walsh, M.M., 1986. Stromatolites from the 3,300-3,500-Myr Swaziland Supergroup, Barberton Mountain Land, South Africa. Nature 319, 489-491.

Byerly, G.R., Palmer, M.R., 1991. Tourmaline mineralization in the Barberton greenstone belt, South Africa: early Archean metasomatism by evaporite-derived boron. Contrib. to Mineral. Petrol. 107, 387-402. https://doi.org/10.1007/BF00325106

Cardona, T., Sánchez-Baracaldo, P., Rutherford, A.W., Larkum, A.W., 2018. Early Archean origin of Photosystem II. Geobiology 4, e00548. https://doi.org/10.1111/gbi.12322

Coffey, J.M., Flannery, D.T., Walter, M.R., George, S.C., 2013. Sedimentology, stratigraphy and geochemistry of a stromatolite biofacies in the $2.72 \mathrm{Ga}$ Tumbiana Formation, Fortescue Group, Western Australia. Precambrian Res. 236, 282-296.

https://doi.org/10.1016/j.precamres.2013.07.021

De Ronde, C.E.J., De Wit, M.J., 1994. Tectonic history of the Barberton greenstone belt, South Africa: 490 million years of Archean crustal evolution. Tectonics 13, 983-1005. https://doi.org/10.1029/94TC00353

De Ronde, C.E.J., Kamo, S.L., 2000. An Archaean arc-arc collisional event: A short-lived (ca 3 Myr) episode, Weltevreden area, Barberton greenstone belt, South Africa. J. African Earth Sci. 30, 219 248. https://doi.org/10.1016/S0899-5362(00)00017-8

De Wit, M.J., Furnes, H., R., 2011. Geology and tectonostratigraphy of the Onverwacht Suite, Barberton Greenstone Belt,. Precambrian Res. 186, 28-50.

de Wit, M.J., Hart, R., Martin, A., Abbott, P., 1982. Archean abiogenic and probable biogenic structures associated with mineralized hydrothermal vent systems and regional metasomatism, with implications for greenstone belt studies. Econ. Geol. 77, 1783-1802. https://doi.org/10.2113/gsecongeo.77.8.1783

782 Engel, A.E.J., Nagy, B., Nagy, L.A., Engel, C.G., Kremp, G.O.W., Drew, C.M., 1968. Alga-Like Forms 
in Onverwacht Series, South Africa: Oldest Recognized Lifelike Forms on Earth. Science (80-. ).

784

785

786

787

788

789

790

791

792

793

794

795

796

797

798

799

800

801

802

803

804

805

806

807

808

809

810

811

812

813

814

815

816 161, 1005-1008. https://doi.org/10.1126/science.161.3845.1005

Eriksson, K.A., 1979. Marginal marine depositional processes from the Archaean Moodies Group, Barberton Mountain Land; South Africa: Evidence and significance. Precambrian Res. 8, 153-182.

Eriksson, K.A., 1977. Tidal deposits from the Archaean Moodies Group, Barberton Mountain Land, South Africa. Sediment. Geol. 18, 257-281.

Fliegel, D., Simonetti, A., Furnes, H., 2010. In-situ dating of the Earth 's oldest trace fossil. https://doi.org/10.1016/j.epsl.2010.09.008

Furnes, H., 2004. Early Life Recorded in Archean Pillow Lavas. Science (80-. ). 304, 578-581. https://doi.org/10.1126/science.1095858

Furnes, H., Banerjee, N.R., Staudigel, H., Muehlenbachs, K., Mcloughlin, N., Wit, M. De, Kranendonk, M. Van, 2007. Comparing petrographic signatures of bioalteration in recent to Mesoarchean pillow lavas : Tracing subsurface life in oceanic igneous rocks 158, 156-176. https://doi.org/10.1016/j.precamres.2007.04.012

Gamper, A., Heubeck, C., Demske, D., Hoehse, M., 2012. Composition and Microfacies of Archean Microbial Mats (Moodies Group, ca. 3.22 Ga, South Africa), in: Noffke, N., Chafetz, H.S. (Eds.), Microbial Mats in Silicilastic Depositional Systems Through Time. SEPM (Society for Sedimentary Geology), Tulsa, pp. 65-74. https://doi.org/10.2110/sepmsp.101.065

Gerdes, G., 2007. Structures Left by Modern Microbial Mats in Their Host Sediments, in: Schieber, J., Bose, P.K., Eriksson, P.., Banerjee, S., Sarkar, S., Altermann, W., Catuneanu, O. (Eds.), Atlas of Microbial Mat Features Preserved within the Siliciclastic Rock Record. Elsevier, Amsterdam, pp. 538. https://doi.org/10.1016/S1574-1966(07)02001-9

Gerdes, G., Klenke, T., Noffke, N., 2000. Microbial signatures in peritidal siliciclastic sediments: a catalogue. Sedimentology 47, 279-308.

Glikson, M., Duck, L.J., Golding, S.D., Hofmann, A., Bolhar, R., Webb, R., Baiano, J.C.F., Sly, L.I., 2008. Microbial remains in some earliest Earth rocks: Comparison with a potential modern analogue. Precambrian Res. 164, 187-200. https://doi.org/10.1016/j.precamres.2008.05.002

Grosch, E.G., McLoughlin, N., 2014. Reassessing the biogenicity of Earth's oldest trace fossil with implications for biosignatures in the search for early life. Proc. Natl. Acad. Sci. 111, 8380-8385. https://doi.org/10.1073/pnas.1402565111

Hall, A.L., 1918. The geology of the Barberton gold mining district. Geol. Surv. South Africa Mem. 9, 347.

Heinrichs, T.K., Reimer, T., 1977. Geology and tectonostratigraphy of the Onverwacht Suite, Barberton greenstone belt, South Africa. Econ. Geol. 72, 1426-1441. 
Heubeck, C., 2009. An early ecosystem of Archean tidal microbial mats (Moodies Group, South Africa, ca. 3.2 Ga). Geology 37, 931-934. https://doi.org/10.1130/G30101A.1

Heubeck, C., Bläsing, S., Grund, M., Drabon, N., Homann, M., Nabhan, S., 2016. Geological constraints on Archean (3.22 Ga) coastal-zone processes from the Dycedale Syncline, Barberton Greenstone Belt. South African J. Geol. 119, 495-518. https://doi.org/10.2113/gssajg.119.3.495

Heubeck, C., Engelhardt, J., Byerly, G.R., Zeh, A., Sell, B., Luber, T., Lowe, D.R., 2013. Timing of deposition and deformation of the Moodies Group (Barberton Greenstone Belt, South Africa): Veryhigh-resolution of Archaean surface processes. Precambrian Res. 231, 236-262. https://doi.org/10.1016/j.precamres.2013.03.021

Heubeck, C., Lowe, D.R., 1999. Sedimentary petrography and provenance of the Archean Moodies Grou, Barberton Greenstone Belt, in: Lowe, D.R., Byerly, G.R. (Eds.), Geologic Evolution of the Barberton Greenstone Belt, South Africa. Geological Society of America Special Paper 329, pp. 259-286.

Heubeck, C., Lowe, D.R., 1994a. Depositional and tectonic setting of the Archean Moodies Group, Barberton greenstone belt, South Africa. Precambrian Res. 68, 257-290.

Heubeck, C., Lowe, D.R., 1994b. Late syndepositional deformation and detachment tectonics in the Barberton Greenstone Belt, South Africa. Tectonics 13, 1514-1536.

Hickman-Lewis, K., Cavalazzi, B., Foucher, F., Westall, F., 2018. Most ancient evidence for life in the Barberton greenstone belt: Microbial mats and biofabrics of the $\sim 3.47$ Ga Middle Marker horizon. Precambrian Res. 312, 45-67. https://doi.org/10.1016/j.precamres.2018.04.007

Hickman-Lewis, K., Westall, F., Cavalazzi, B., 2019. Traces of Early Life From the Barberton Greenstone Belt, South Africa, in: Earth's Oldest Rocks. Elsevier B.V., pp. 1029-1058. https://doi.org/10.1016/B978-0-444-63901-1.00042-3

Hofmann, A., 2005. The geochemistry of sedimentary rocks from the Fig Tree Group, Barberton greenstone belt: Implications for tectonic, hydrothermal and surface processes during mid-Archaean times. Precambrian Res. 143, 23-49. https://doi.org/10.1016/j.precamres.2005.09.005

Hofmann, A., Bolhar, R., 2007. Carbonaceous cherts in the Barberton greenstone belt and their significance for the study of early life in the Archean record. Astrobiology 7, 355-388. https://doi.org/10.1089/ast.2005.0288

Hofmann, A., Harris, C., 2008. Silica alteration zones in the Barberton greenstone belt : A window into subsea floor processes 3.5 - 3.3 Ga ago. Chem. Geol. 257, 221-239. https://doi.org/10.1016/j.chemgeo.2008.09.015

Homann, M., Heubeck, C., Airo, A., Tice, M.M., 2015. Morphological adaptations of 3.22 Ga-old tufted microbial mats to Archean coastal habitats (Moodies Group, Barberton Greenstone Belt, South 

Africa). Precambrian Res. 266, 47-64. https://doi.org/10.1016/j.precamres.2015.04.018

Homann, M., Heubeck, C., Bontognali, T.R.R., Bouvier, A.S., Baumgartner, L.P., Airo, A., 2016. Evidence for cavity-dwelling microbial life in 3.22 Ga tidal deposits. Geology 44, 51-54. https://doi.org/10.1130/G37272.1

Homann, M., Sansjofre, P., Van Zuilen, M., Heubeck, C., Gong, J., Killingsworth, B., Foster, I.S., Airo, A., Van Kranendonk, M.J., Ader, M., Lalonde, S. V, 2018. Microbial life and biogeochemical cycling on land 3,220 million years ago. Nat. Geosci. 11, 665-671. https://doi.org/10.1038/s41561018-0190-9

House, C.H., Oehler, D.Z., Sugitani, K., Mimura, K., 2013. Carbon isotopic analyses of ca. $3.0 \mathrm{Ga}$ microstructures imply planktonic autotrophs inhabited earth's early oceans. Geology 41, 651-654. https://doi.org/10.1130/G34055.1

Jahnert, R.J., Collins, L.B., 2013. Controls on microbial activity and tidal flat evolution in Shark Bay, Western Australia. Sedimentology 60, 1071-1099. https://doi.org/10.1111/sed.12023

Jakubowicz, M., Berkowski, B., Belka, Z., 2014. Cryptic coral-crinoid "hanging gardens" from the Middle Devonian of southern Morocco. Geology 42, 119-122. https://doi.org/10.1130/G35217.1

Javaux, E.J., Marshall, C.P., Bekker, A., 2010. Organic-walled microfossils in 3.2-billion-year-old shallow-marine siliciclastic deposits. Nature 463, 934-8. https://doi.org/10.1038/nature08793

Karkhanis, S.N., 1977. Artifacts produced by chemical processing of samples for micropalaeontology and organic geochemistry - a note of caution. Precambrian Res. 4, 229-236. https://doi.org/10.1016/0301-9268(77)90015-8

Knauth, L.P., Lowe, D.R., 2003. High Archean climatic temperature inferred from oxygen isotope geochemistry of cherts in the 3.5 Ga Swaziland Supergroup, South Africa. Bull. Geol. Soc. Am. 115, 566-580. https://doi.org/10.1130/0016-7606(2003)115<0566:HACTIF>2.0.CO;2

Knoll, A.H., Barghoorn, E.S., 1977. Archean Microfossils Showing Cell Division from the Swaziland System of South Africa. Science (80-. ). 198, 396-398. https://doi.org/10.1126/science.198.4315.396

Kobluk, D.R., James, N.P., 1979. Cavity-dwelling organisms in Lower Cambrian patch reefs from southern Labrador. Lethaia 12, 193-218. https://doi.org/10.1111/j.1502-3931.1979.tb00997.x.

Kozawa, T., Sugitani, K., Oehler, D.Z., House, C.H., Saito, I., Watanabe, T., Gotoh, T., 2018. Early Archean planktonic mode of life: Implications from fluid dynamics of lenticular microfossils. Geobiology 1-14. https://doi.org/10.1111/gbi.12319

Kremer, B., Kaźmierczak, J., 2017. Cellularly preserved microbial fossils from 3.4 Ga deposits of South Africa: A testimony of early appearance of oxygenic life? Precambrian Res. 295, 117-129. https://doi.org/10.1016/j.precamres.2017.04.023 
885 Kröner, A., Byerly, G.R., Lowe, D.R., 1991. Chronology of early Archaean granite-greenstone evolution 886 in the Barberton Mountain Land, South Africa, based on precise dating by single zircon evaporation. Earth Planet. Sci. Lett. 103, 41-54.

Kröner, A., Hegner, E., Wendt, J.I., Byerly, G.R., 1996. The oldest part of the Barberton granitoidgreenstone terrain, South Africa: evidence for crust formation between 3.5 and 3.7 Ga. Precambrian Res. 78, 105-124. https://doi.org/10.1016/0301-9268(95)00072-0

Lamb, S., Paris, I., 1988. Post-onverwacht group stratigraphy in the SE part of the Archaean Barbeton greenstone belt. J. African Earth Sci. (and Middle East) 7, 285-306. https://doi.org/10.1016/08995362(88)90074-7

Lanier, W.P., Lowe, D.R., 1982. Sedimentology of the Middle Marker (3.4 Ga), Onverwacht Group, Transvaal, South Africa. Precambrian Res. 18, 237-260. https://doi.org/10.1016/03019268(82)90012-2

Lepot, K., Williford, K.H., Ushikubo, T., Sugitani, K., Mimura, K., Spicuzza, M.J., Valley, J.W., 2013. Texture-specific isotopic compositions in 3.4 Gyr old organic matter support selective preservation in cell-like structures. Geochim. Cosmochim. Acta 112, 66-86. https://doi.org/10.1016/j.gca.2013.03.004

Lowe, D.R., 1999a. Geologic evolution of the Barberton Greenstone Belt and vicinity, in: Lowe, D.R., Byerly, G.. (Ed.), Special Paper 329: Geologic Evolution of the Barberton Greenstone Belt, South Africa. Geological Society of America, pp. 287-312. https://doi.org/10.1130/0-8137-2329-9.287

Lowe, D.R., 1999b. Petrology and sedimentology of cherts and related silicified sedimentary rocks in the Swaziland Supergroup, in: Lowe, D.R., Byerly, G.R. (Eds.), Geologic Evolution of the Barberton Greenstone Belt, South Africa. Geological Society of America, p. 0. https://doi.org/10.1130/0-81372329-9.83

Lowe, D.R., 1999c. Shallow-water sedimentation of accretionary lapilli-bearing strata of the Msauli Chert: Evidence of explosive hydromagmatic komatiitic volcanism, in: Special Paper 329: Geologic Evolution of the Barberton Greenstone Belt, South Africa. Geological Society of America, pp. 213232. https://doi.org/10.1130/0-8137-2329-9.213

Lowe, D.R., 1994. Accretionary history of the Archean Barberton greenstone belt (3.55-3.22 Ga), southern Africa. Geology 22, 1099-1102.

Lowe, D.R., Byerly, G.R., 2018. The terrestrial record of Late Heavy Bombardment. New Astron. Rev. 81, 39-61. https://doi.org/10.1016/j.newar.2018.03.002

Lowe, D.R., Byerly, G.R., 2015. Geologic record of partial ocean evaporation triggered by giant asteroid impacts, 3.29-3.23 billion years ago. Geology 43, 535-538. https://doi.org/10.1130/G36665.1

Lowe, D.R., Byerly, G.R., 2007. Ironstone bodies of the Barberton greenstone belt, South Africa: 
Products of a Cenozoic hydrological system, not Archean hydrothermal vents! GSA Bull. 119, 6587. https://doi.org/10.1130/b25997.1

Lowe, D.R., Byerly, G.R., 1999. Stratigraphy of the west-central part of the Barberton Greenstone Belt, South Africa, in: Lowe, D.R., Byerly, G.R. (Eds.), Geologic Evolution of the Barberton Greenstone Belt, South Africa. Geological Society of America Special Paper 329, pp. 1-36.

Lowe, D.R., Byerly, G.R., 1986. Early Archean silicate spherules of probable impact origin, South Africa and Western Australia. Geology 14, 83. https://doi.org/10.1130/00917613(1986)14<83:EASSOP $>2.0 . C O ; 2$

Lowe, D.R., Byerly, G.R., Asaro, F., Kyte, F.J., 1989. Geological and Geochemical Record of 3400Million-Year-Old Terrestrial Meteorite Impacts. Science (80-. ). 245, 959-962. https://doi.org/10.1126/science.245.4921.959

Lowe, D.R., Byerly, G.R., Heubeck, C., 2012. Geologic Map of the west-central Barberton Greenstone Belt, in: South Africa, Scale 1:25,000. Geological Society of America Map and Chart Series No. 103, Boulder. https://doi.org/10.1130/2012. MCH103

Lowe, D.R., Knauth, L.P., 1977. Sedimentology of the Onverwacht Group (3.4 Billion Years), Transvaal, South Africa, and Its Bearing on the Characteristics and Evolution of the Early Earth. J. Geol. 85, 699-723. https://doi.org/10.1086/628358

Lowe, D.R., Worrell, G.F., 1999. Sedimentology, mineralogy, and implications of silicified evaporites in the Kromberg Formation, Barberton Greenstone Belt, South Africa, in: Special Paper 329: Geologic Evolution of the Barberton Greenstone Belt, South Africa. Geological Society of America, pp. 167188. https://doi.org/10.1130/0-8137-2329-9.167

Mcloughlin, N., Grosch, E.G., Kilburn, M.R., Wacey, D., 2012. Sulfur isotope evidence for a Paleoarchean subseafl oor biosphere, Barberton, South Africa 1031-1035. https://doi.org/10.1130/G33313.1

Muir, M.D., Grant, P.R., 1976. Micropalaeontological evidence from the Onverwacht Group, South Africa, in: Windley, B.. (Ed.), The Early History of the Earth. John Wiley \& Sons, New York, pp. 595-608.

Muir, M.D., Hall, D.O., 1974. Diverse microfossils in Precambrian Onverwacht group rocks of South Africa. Nature 252, 376-378. https://doi.org/10.1038/252376a0

Nabhan, S., Luber, T., Scheffler, F., Heubeck, C., 2016a. Climatic and geochemical implications of Archean pedogenic gypsum in the Moodies Group ( 3.2 Ga), Barberton Greenstone Belt, South Africa. Precambrian Res. 275, 119-134. https://doi.org/10.1016/j.precamres.2016.01.011

Nabhan, S., Wiedenbeck, M., Milke, R., Heubeck, C., 2016b. Biogenic overgrowth on detrital pyrite in ca. 3.2 Ga Archean paleosols. Geology 44, 763-766. https://doi.org/10.1130/G38090.1 
953

954

955

956

957

958

959

960

961

962

963

964

965

966

967

968

969

970

971

972

973

974

975

976

977

978

979

980

981

982

983

984

985

986

Nagy, B., Nagy, L.A., 1969. Early Pre-Cambrian Onverwacht Microstructures : Possibly the Oldest Fossils on Earth? Nature 223, 1226-1229. https://doi.org/10.1038/2231226a0

Noffke, N., Eriksson, K.A., Hazen, R.M., Simpson, E.L., 2006. A new window into Early Archean life: Microbial mats in Earth's oldest siliciclastic tidal deposits (3.2 Ga Moodies Group, South Africa). Geology 34, 253. https://doi.org/10.1130/G22246.1

Nutman, A.P., Bennett, V.C., Friend, C.R.L., Van Kranendonk, M.J., Chivas, A.R., 2016. Rapid emergence of life shown by discovery of 3,700-million-year-old microbial structures. Nature 537, 535-538. https://doi.org/10.1038/nature19355

Oehler, D.Z., Schopf, J.W., Kvenvolden, K.A., 1972. Carbon Isotopic Studies of Organic Matter in Precambrian Rocks. Science (80-. ). 175, 1246-1248. https://doi.org/10.1126/science.175.4027.1246

Oehler, D.Z., Walsh, M.M., Sugitani, K., Liu, M.C., House, C.H., 2017. Large and robust lenticular microorganisms on the young Earth. Precambrian Res. 296, 112-119. https://doi.org/10.1016/j.precamres.2017.04.031

Oehler, D.Z., Walter, M.R., Sugitani, K., Allwood, A., Meibom, A., Mostefaoui, S., Selo, M., Thomen, A., Gibson, E.K., 2009. NanoSIMS : Insights to biogenicity and syngeneity of Archaean carbonaceous structures 173, 70-78. https://doi.org/10.1016/j.precamres.2009.01.001

Otálora, F., Mazurier, A., Garcia-Ruiz, J.M., Van Kranendonk, M.J., Kotopoulou, E., El Albani, A., Garrido, C.J., 2018. A crystallographic study of crystalline casts and pseudomorphs from the $3.5 \mathrm{Ga}$ dresser formation, Pilbara Craton (Australia). J. Appl. Crystallogr. 51, 1050-1058. https://doi.org/10.1107/S1600576718007343

Pflug, H.D., 1967. Structured organic remains from the Fig Tree Series (Precambrian) of the Barberton mountain land (South Africa). Rev. Palaeobot. Palynol. 5, 9-29. https://doi.org/10.1016/00346667(67)90205-9

Pflug, H.D., 1966. Structured organic remains from the Fig Tree Series (Precambrian) of the Barberton Mountain land (South Africa). Econ. Geol. Res. Unit, Univ. Witwatersrand, Johannesburg, Inform. Circ. 28, 14.

Pflug, H.D., Meinel, W., Neumann, K.H., Meinel, M., 1969. Entwicklungstendenzen des frühen Lebens auf der Erde. Naturwissenschaften 56, 10-14. https://doi.org/10.1007/BF00599585

Rasmussen, B., Blake, T.S., Fletcher, I.R., Kilburn, M.R., 2009. Evidence for microbial life in synsedimentary cavities from 2.75 Ga terrestrial environments. Geology 37, 423-426. https://doi.org/10.1130/G25300A.1

Schieber, J., Bose, P.K., Eriksson, P.G., 2007. Atlas of microbial mat features preserved within the siliciclastic rock record. Elsevier, Amsterdam.

Schopf, J.W., 2004. Geochemical and submicron-scale morphologic analyses of individual Precambrian 
microorganisms. Geochemical Soc. Spec. Publ. 365-375.

Schopf, J.W., 1975. Precambrian Paleobiology: Problems and Perspectives. Annu. Rev. Earth Planet. Sci. 3, 213-249. https://doi.org/10.1146/annurev.ea.03.050175.001241

Schopf, J.W., Barghoorn, E.S., 1967. Alga-Like Fossils from the Early Precambrian of South Africa. Science (80-. ). 156, 508-512. https://doi.org/10.1126/science.156.3774.508

Schopf, J.W., Walter, M.R., 1983. Archean microfossils: new evidence of ancient microbes, in: Schopf, J.W. (Ed.), Earth's Earliest Biosphere: Its Origin and Evolution. Princeton University Press, Princeton, pp. 214-239.

Simpson, E.L., Eriksson, K.A., Mueller, W.U., 2012.3.2 Ga eolian deposits from the Moodies Group, Barberton Greenstone Belt, South Africa: Implications for the origin of first-cycle quartz sandstones. Precambrian Res. 214-215, 185-191. https://doi.org/10.1016/j.precamres.2012.01.019

Sleep, N.H., Zahnle, K.J., Kasting, J.F., Morowitz, H.J., 1989. Annihilation of ecosystems by large asteroid impacts on the early Earth. Nature 342, 139-142. https://doi.org/10.1038/342139a0

Staudigel, H., Furnes, H., Dewit, M., 2015. Paleoarchean trace fossils in altered volcanic glass 112. https://doi.org/10.1073/pnas.1421052112

Stüeken, E.E., Kipp, M.A., Koehler, M.C., Buick, R., 2016. The evolution of Earth's biogeochemical nitrogen cycle. Earth-Science Rev. 160, 220-239. https://doi.org/10.1016/j.earscirev.2016.07.007

Sugitani, K., Grey, K., Allwood, A., Nagaoka, T., Mimura, K., Minami, M., Marshall, C.P., Van Kranendonk, M.J., Walter, M.R., 2007. Diverse microstructures from Archaean chert from the Mount Goldsworthy-Mount Grant area, Pilbara Craton, Western Australia: Microfossils, dubiofossils, or pseudofossils? Precambrian Res. 158, 228-262.

https://doi.org/10.1016/j.precamres.2007.03.006

Sugitani, K., Lepot, K., Nagaoka, T., Mimura, K., Van Kranendonk, M., Oehler, D.Z., Walter, M.R., 2010. Biogenicity of Morphologically Diverse Carbonaceous Microstructures from the $c a$. $3400 \mathrm{Ma}$ Strelley Pool Formation, in the Pilbara Craton, Western Australia. Astrobiology 10, 899-920. https://doi.org/10.1089/ast.2010.0513

Sugitani, K., Mimura, K., Nagaoka, T., Lepot, K., Takeuchi, M., 2013. Microfossil assemblage from the 3400Ma Strelley Pool Formation in the Pilbara Craton, Western Australia: Results form a new locality. Precambrian Res. 226, 59-74. https://doi.org/10.1016/j.precamres.2012.11.005

Taj, R.J., Aref, M. a. M., Schreiber, B.C., 2014. The influence of microbial mats on the formation of sand volcanoes and mounds in the Red Sea coastal plain, south Jeddah, Saudi Arabia. Sediment. Geol. 311, 60-74. https://doi.org/10.1016/j.sedgeo.2014.06.006

Tice, M.M., 2009. Environmental Controls on Photosynthetic Microbial Mat Distribution and Morphogenesis on a 3.42Ga Clastic-Starved Platform. Astrobiology 9, 989-1000. 
Tice, M.M., Bostick, B.C., Lowe, D.R., 2004. Thermal history of the 3.5-3.2 Ga Onverwacht and Fig Tree Groups, Barberton greenstone belt, South Africa, inferred by Raman microspectroscopy of carbonaceous material. Geology 32, 37-40. https://doi.org/10.1130/G19915.1

Tice, M.M., Lowe, D.R., 2006a. The origin of carbonaceous matter in pre-3.0 Ga greenstone terrains: A review and new evidence from the 3.42 Ga Buck Reef Chert. Earth-Science Rev. 76, 259-300. https://doi.org/10.1016/j.earscirev.2006.03.003

Tice, M.M., Lowe, D.R., 2006b. Hydrogen-based carbon fixation in the earliest known photosynthetic organisms. Geology 34, 37. https://doi.org/10.1130/G22012.1

Tice, M.M., Lowe, D.R., 2004. Photosynthetic microbial mats in the 3, 416-Myr-old ocean. Nature 431, 549-552. https://doi.org/10.1038/nature02920.1.

Tice, M.M., Thornton, D.C.O., Pope, M.C., Olszewski, T.D., Gong, J., 2011. Archean Microbial Mat Communities. Annu. Rev. Earth Planet. Sci. 39, 297-319. https://doi.org/10.1146/annurev-earth040809-152356

Toulkeridis, T., Goldstein, S.L., Clauer, N., Kröner, A., Todt, W., Schidlowski, M., 1998. Sm-Nd, Rb-Sr and $\mathrm{Pb}-\mathrm{Pb}$ dating of silicic carbonates from the early Archaean Barberton Greenstone Belt, South Africa: evidence for post-depositional isotopic resetting at low temperature. Precambrian Res. 92, $129-144$.

Trower, E.J., Lowe, D.R., 2016. Sedimentology of the 3.3Ga upper Mendon Formation, Barberton Greenstone Belt, South Africa. Precambrian Res. 281, 473-494.

https://doi.org/10.1016/j.precamres.2016.06.003

Van Kranendonk, M.J., Philippot, P., Lepot, K., Bodorkos, S., Pirajno, F., 2008. Geological setting of Earth's oldest fossils in the ca. 3.5 Ga Dresser Formation, Pilbara Craton, Western Australia. Precambrian Res. 167, 93-124. https://doi.org/10.1016/j.precamres.2008.07.003

van Zuilen, M.A., Chaussidon, M., Rollion-Bard, C., Marty, B., 2007. Carbonaceous cherts of the Barberton Greenstone Belt, South Africa: Isotopic, chemical and structural characteristics of individual microstructures. Geochim. Cosmochim. Acta 71, 655-669. https://doi.org/10.1016/j.gca.2006.09.029

Viljoen, M.J., Viljoen, R.P., 1969. An introduction to the geology of the Barberton granite-greenstone terrain. Spec. Publ. Geol. Soc. S. Afr 2, 9-28.

Visser, D., 1956. The geology of the Barberton area. Geol. Soc. S. Afr. Spec. Publ. 15, 253.

Wacey, D., 2012. Earliest evidence for life on Earth: An Australian perspective. Aust. J. Earth Sci. 59, 153-166. https://doi.org/10.1080/08120099.2011.592989

Wacey, D., 2009. Early Life on Earth. A Practical Guide, Topics in Geobiology, Vol. 31. Springer. Wacey, D., Fisk, M., Saunders, M., Eiloart, K., Kong, C., 2017. Critical testing of potential cellular 
structures within microtubes in 145 Ma volcanic glass from the Argo Abyssal Plain. Chem. Geol. 466, 575-587. https://doi.org/10.1016/j.chemgeo.2017.07.006

Wacey, D., Noffke, N., Saunders, M., Guagliardo, P., Pyle, D.M., 2018a. Volcanogenic Pseudo-Fossils from the $\sim 3.48 \mathrm{Ga}$ Dresser Formation, Pilbara, Western Australia. Astrobiology 18, ast.2017.1734. https://doi.org/10.1089/ast.2017.1734

Wacey, D., Saunders, M., Kong, C., 2018b. Remarkably preserved tephra from the 3430 Ma Strelley Pool Formation, Western Australia: Implications for the interpretation of Precambrian microfossils. Earth Planet. Sci. Lett. 487, 33-43. https://doi.org/10.1016/j.eps1.2018.01.021

Walsh, M.M., 2004. Evaluation of Early Archean Volcaniclastic and Volcanic Flow Rocks as Possible Sites for Carbonaceous Fossil Microbes. Astrobiology 4, 429-437. https://doi.org/10.1089/ast.2004.4.429

Walsh, M.M., 1992. Microfossils and possible microfossils from the Early Archean Onverwacht Group, Barberton Mountain Land, South Africa. Precambrian Res. 54, 271-293.

Walsh, M.M., Lowe, D.R., 1999. Modes of accumulation of carbonaceous matter in the Early Archean: a petrographic and geochemical study of the carbonaceous cherts of the Swaziland Supergroup, in: Lowe, D.R., Byerly, G.R. (Eds.), Geologic Evolution of the Barberton Greenstone Belt, South Africa. Geological Society of America Special Paper 329, pp. 115-132.

Walsh, M.M., Lowe, D.R., 1985. Filamentous microfossils from the 3,500-Myr-old Onverwacht Group, Barberton Mountain Land, South Africa. Nature 314, 530-531.

Walter, M.R., Buick, R., Dunlop, J.S.R., 1980. Stromatolites 3,400-3,500 Myr old from the North Pole area, Western Australia. Nature. https://doi.org/10.1038/284443a0

Westall, F., Campbell, K.A., Bréhéret, J.G., Foucher, F., Gautret, P., Hubert, A., Sorieul, S., Grassineau, N., Guido, D.M., 2015. Archean (3.33 Ga) microbe-sediment systems were diverse and flourished in a hydrothermal context. Geology 43, 615-618. https://doi.org/10.1130/G36646.1

Westall, F., Cavalazzi, B., Lemelle, L., Marrocchi, Y., Rouzaud, J.N., Simionovici, A., Salomé, M., Mostefaoui, S., Andreazza, C., Foucher, F., Toporski, J., Jauss, A., Thiel, V., Southam, G., MacLean, L., Wirick, S., Hofmann, A., Meibom, A., Robert, F., Défarge, C., 2011. Implications of in situ calcification for photosynthesis in a $\sim 3.3 \mathrm{Ga}$-old microbial biofilm from the Barberton greenstone belt, South Africa. Earth Planet. Sci. Lett. 310, 468-479.

https://doi.org/10.1016/j.eps1.2011.08.029

Westall, F., de Ronde, C.E.., Southam, G., Grassineau, N., Colas, M., Cockell, C., Lammer, H., 2006. Implications of a 3.472-3.333 Gyr-old subaerial microbial mat from the Barberton greenstone belt, South Africa for the UV environmental conditions on the early Earth. Philos. Trans. R. Soc. B Biol. Sci. 361, 1857-1876. https://doi.org/10.1098/rstb.2006.1896 
Westall, F., De Wit, M.J., Dann, J., Van der Gaast, S., De Ronde, C.E.J., Gerneke, D., 2001. Early archean fossil bacteria and biofilms in hydrothermally-influenced sediments from the Barberton greenstone belt, South Africa. Precambrian Res. 106, 93-116. https://doi.org/10.1016/S03019268(00)00127-3

Westall, F., Hickman-Lewis, K., Hinman, N., Gautret, P., Campbell, K.A., Bréhéret, J.G., Foucher, F., Hubert, A., Sorieul, S., Dass, A.V., Kee, T.P., Georgelin, T., Brack, A., 2018. A HydrothermalSedimentary Context for the Origin of Life. Astrobiology 18, 259-293. https://doi.org/10.1089/ast.2017.1680

Williford, K.H., Ushikubo, T., Lepot, K., Kitajima, K., Hallmann, C., Spicuzza, M.J., Kozdon, R., Eigenbrode, J.L., Summons, R.E., Valley, J.W., 2016. Carbon and sulfur isotopic signatures of ancient life and environment at the microbial scale: Neoarchean shales and carbonates. Geobiology 14, 105-128. https://doi.org/10.1111/gbi.12163

Williford, K.H., Ushikubo, T., Schopf, J.W., Lepot, K., Kitajima, K., Valley, J.W., 2013. Preservation and detection of microstructural and taxonomic correlations in the carbon isotopic compositions of individual Precambrian microfossils. Geochim. Cosmochim. Acta 104, 165-182. https://doi.org/10.1016/j.gca.2012.11.005

Xie, X., Byerly, G.R., Ferrell Jr., R.E., 1997. Ilb trioctahedral chlorite from the Barberton greenstone belt: crystal structure and rock composition constraints with implications to geothermometry. Contrib. to Mineral. Petrol. 126, 275-291. https://doi.org/10.1007/s004100050250 


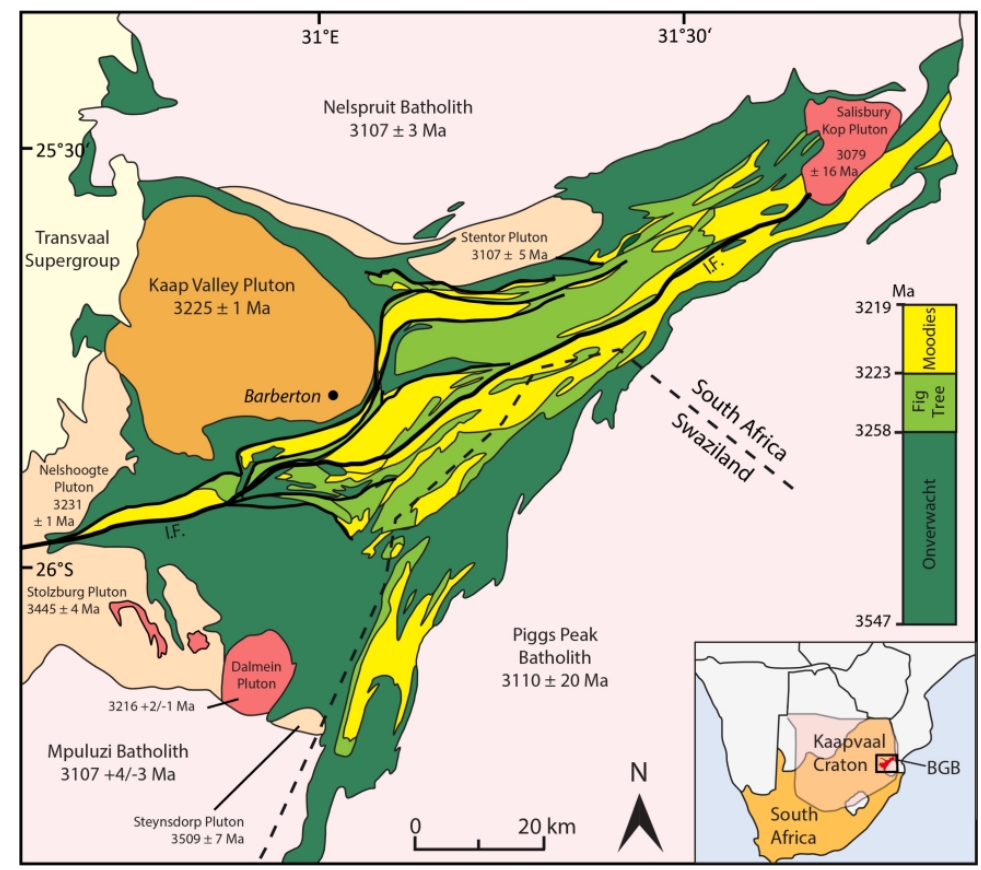

Fig. 1. Geological map of the Barberton Greenstone Belt (BGB) of South Africa and Swaziland and its surrounding plutons in the eastern part of the Kaapvaal Craton. The Barberton Supergroup comprises from base to top the Onverwacht, Fig Tree, and Moodies Group. 


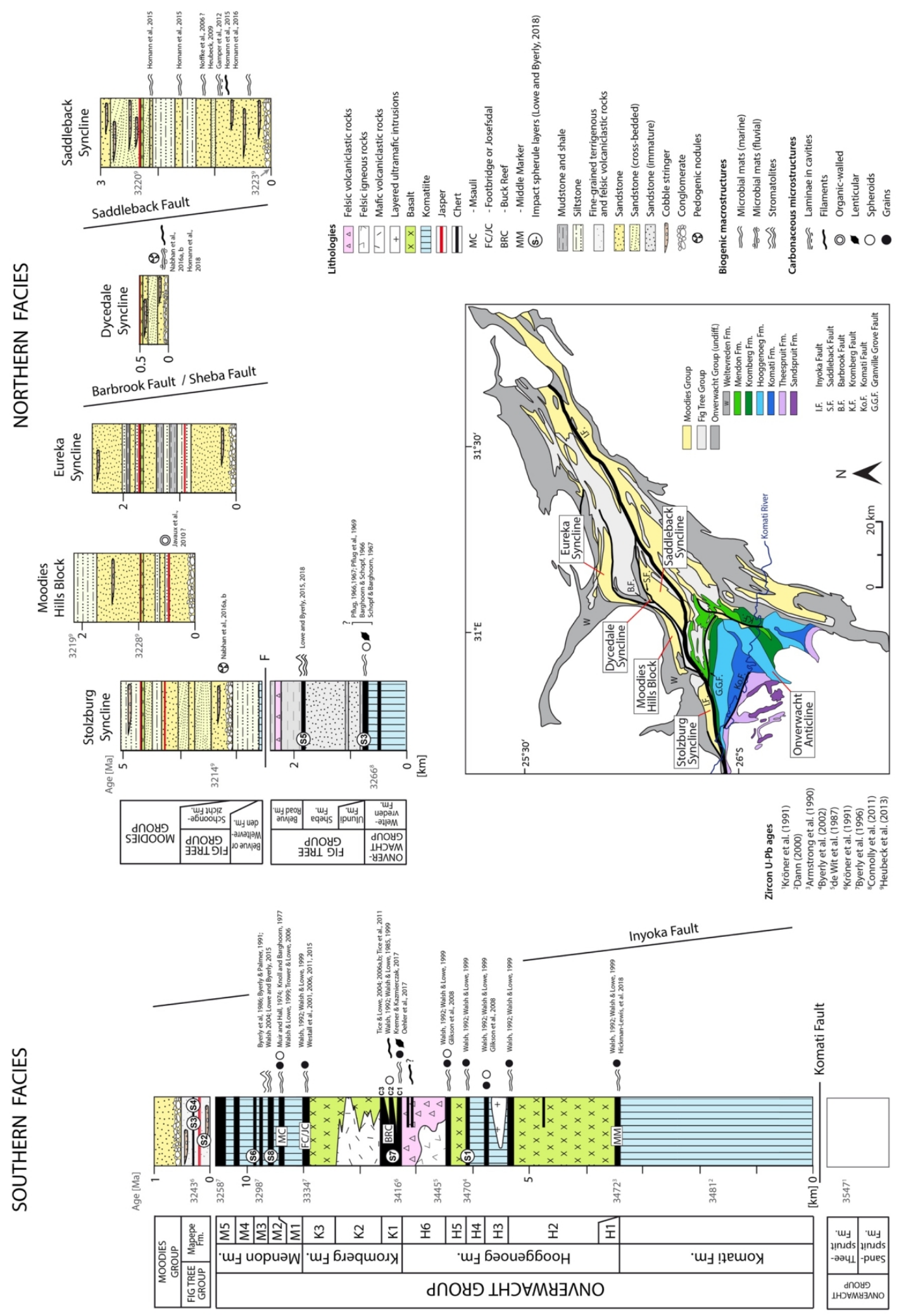

Fig. 2. Generalized stratigraphy and structure of the Barberton Supergroup north and south of the Inyoka Fault (mod. after Lowe and Byerly, 1999) with indicated stratigraphic position of reported macro- and microscopic traces of Paleoarchean life in the Barberton Greenstone Belt. 

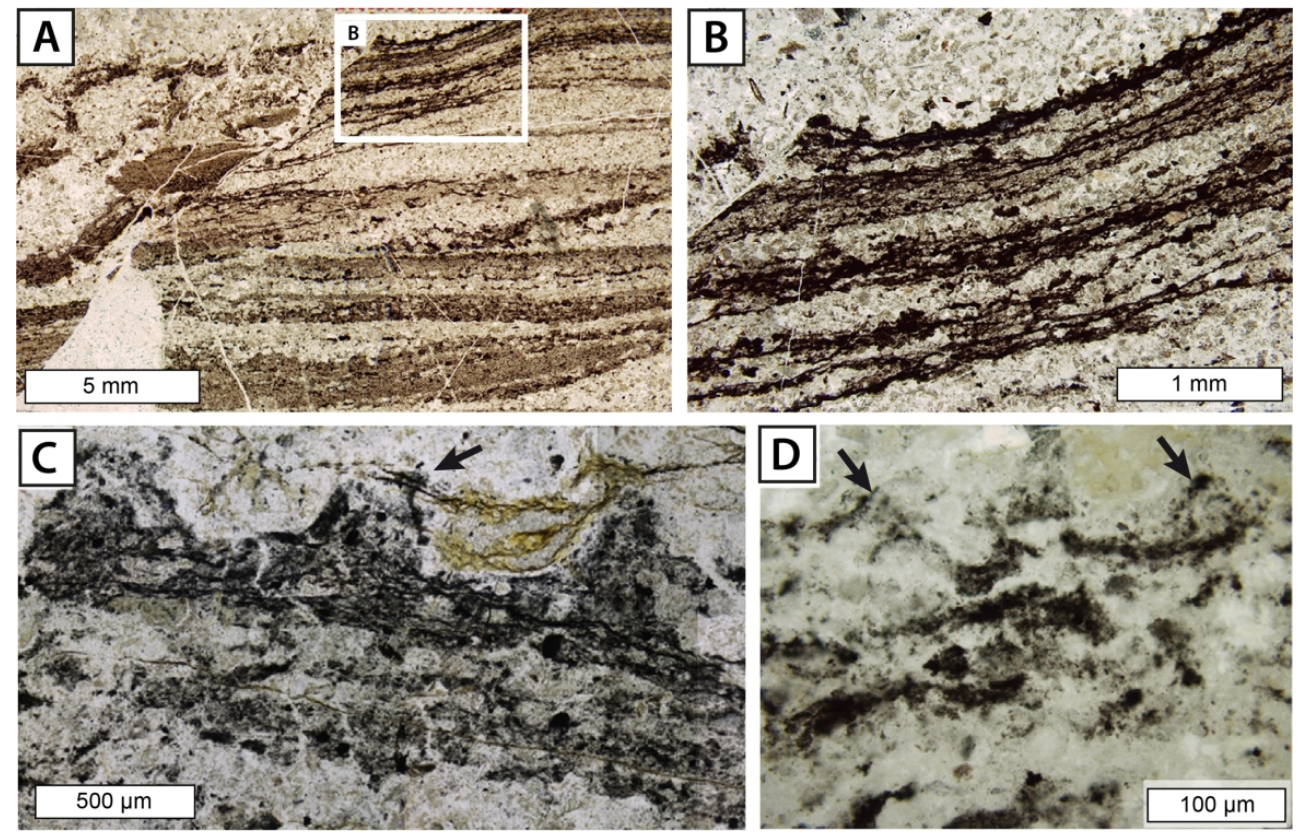

Fig. 3. Photomicrographs of carbonaceous laminations from silicified volcaniclastic sediments of the 3.47 Ga Middle Marker interpreted as remnants of microbial mats. A) Multi-layered mats on horizontallylaminated and cross-bedded sediments, disrupted by secondary fracture. B) Close-up view of crinkly, 'micro-tufted' laminations. C and D) Laminations with secondary 'pseudo-tufted' morphology (arrows), which likely formed due to plastic deformation. Images (A-D) from Hickman-Lewis et al. (2018). 

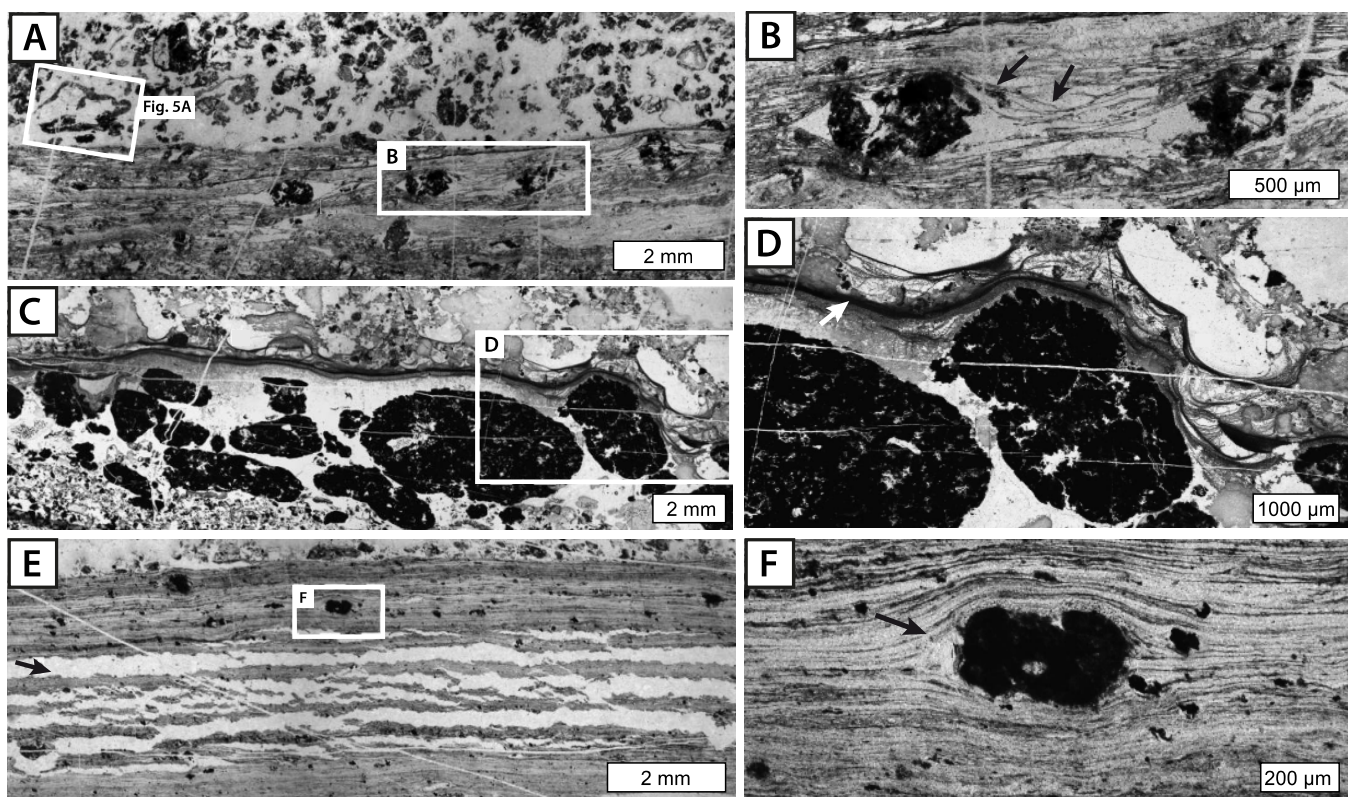

Fig. 4. Photomicrographs of morphologically diverse types of carbonaceous laminations preserved in the $3.42 \mathrm{Ga}$ Buck Reef Chert and interpreted as fossil microbial mats. A and B) Alpha-type laminations loosely draping trapped grains (arrows) and overlain by detrital sediment layer with eroded mat fragment. $\mathrm{C}$ and D) Beta-type laminations with fine meshworks of filament-like strands that drape underlying detrital carbonaceous and silica grains (arrow). E) Gamma-type laminations dissected by early diagenetic silica veins subparallel to bedding (arrow), likely formed due to fluid escape from the sediment. F) Close-up view showing flat carbonaceous laminations, which tightly drape a detrital grain (arrow). Images $(A-F)$

from Tice (2009).
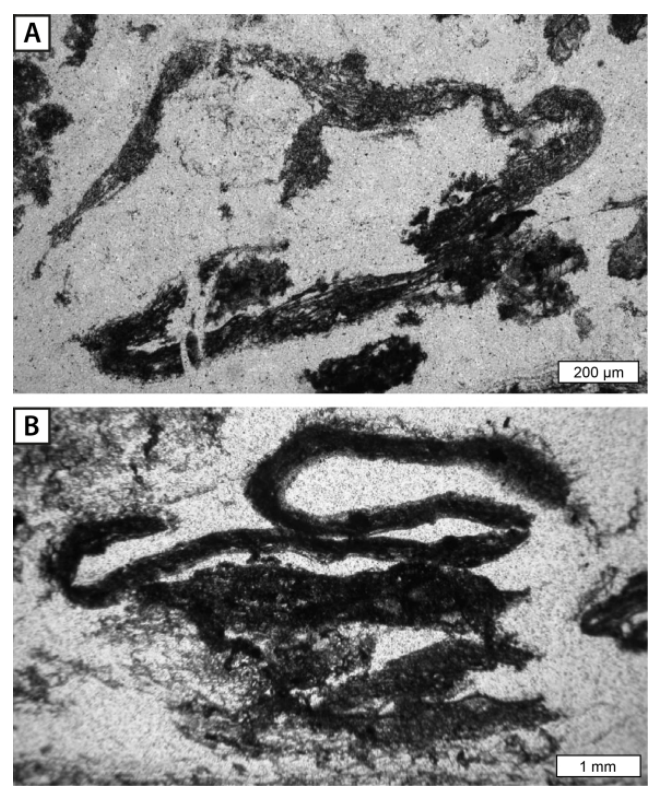

Fig. 5. Photomicrographs of eroded and rolled-up microbial mat fragments from the Buck Reef Chert. A) Close-up view of boxed area in Fig. 4A showing a plastically-deformed segment of alpha-type mat. B) Large, rolled-up fragment of a beta-type mat. Image (A) from Tice (2009) and (B) from Tice and Lowe $2006 b$. 

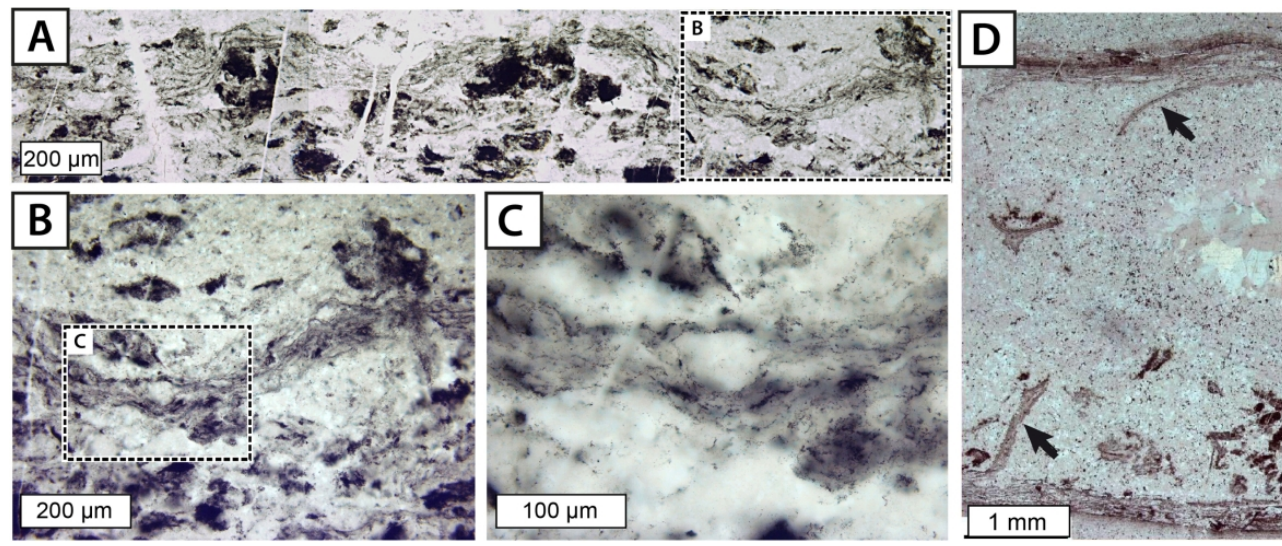

Fig. 6. Photomicrographs of microbial biofilms preserved in the $3.33 \mathrm{Ga}$ Josefsdal Chert. A) Wispy anastomosing laminations that coat and stabilize the underlying sediments. B and C) Close-up views of the fine carbonaceous layers. D) Partially eroded fragments facing down and upwards (arrows) indicate pliable consistency of the biofilms. Images (A-C) from Westall et al. (2011); Image (D) from Westall et al. (2015).
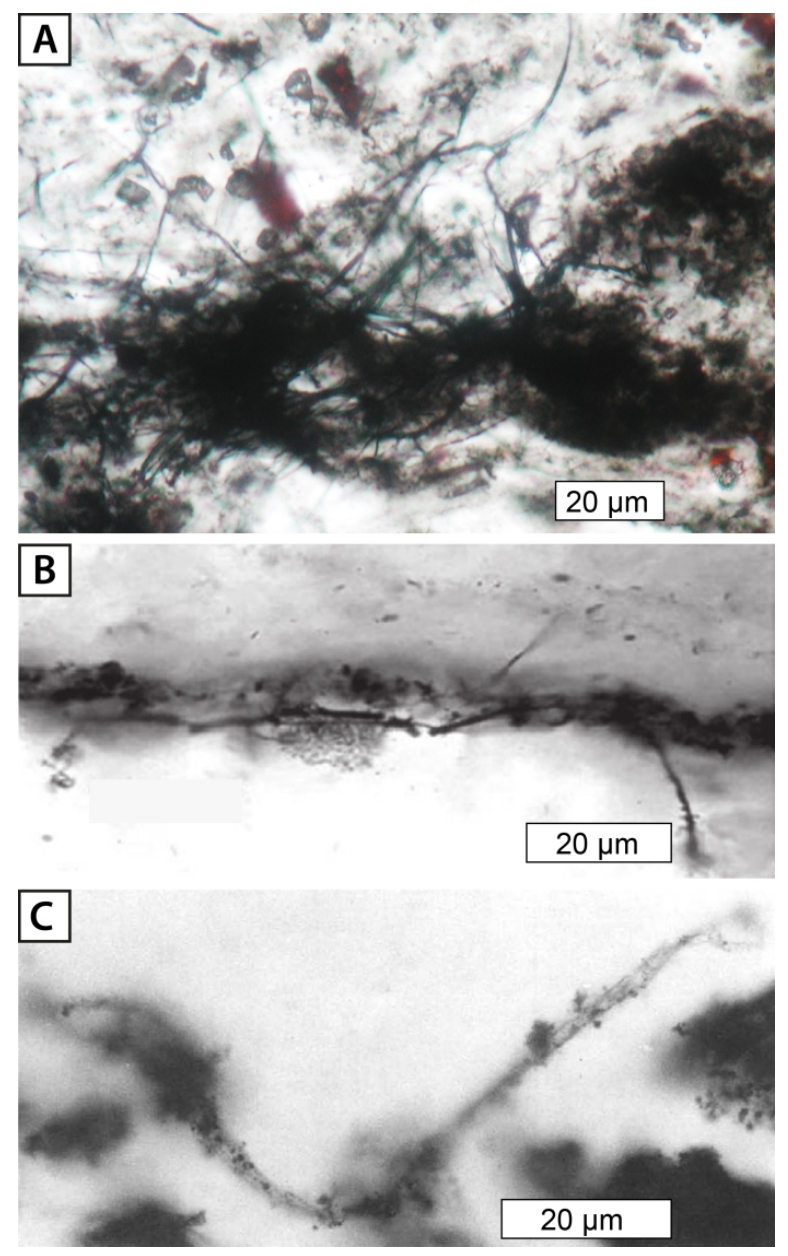

Fig. 7. Photomicrographs of filamentous microstructures from the Buck Reef Chert (Kromberg Formation). A) Interwoven clumps of filamentous microfossils. B) Hollow cylindrical filaments oriented subparallel to bedding. C) Solitary, slightly twisted hollow filament. Image (A) courtesy of Maud M. Walsh; Image (B) from Walsh (2000); Image (C) from Walsh (1992). 

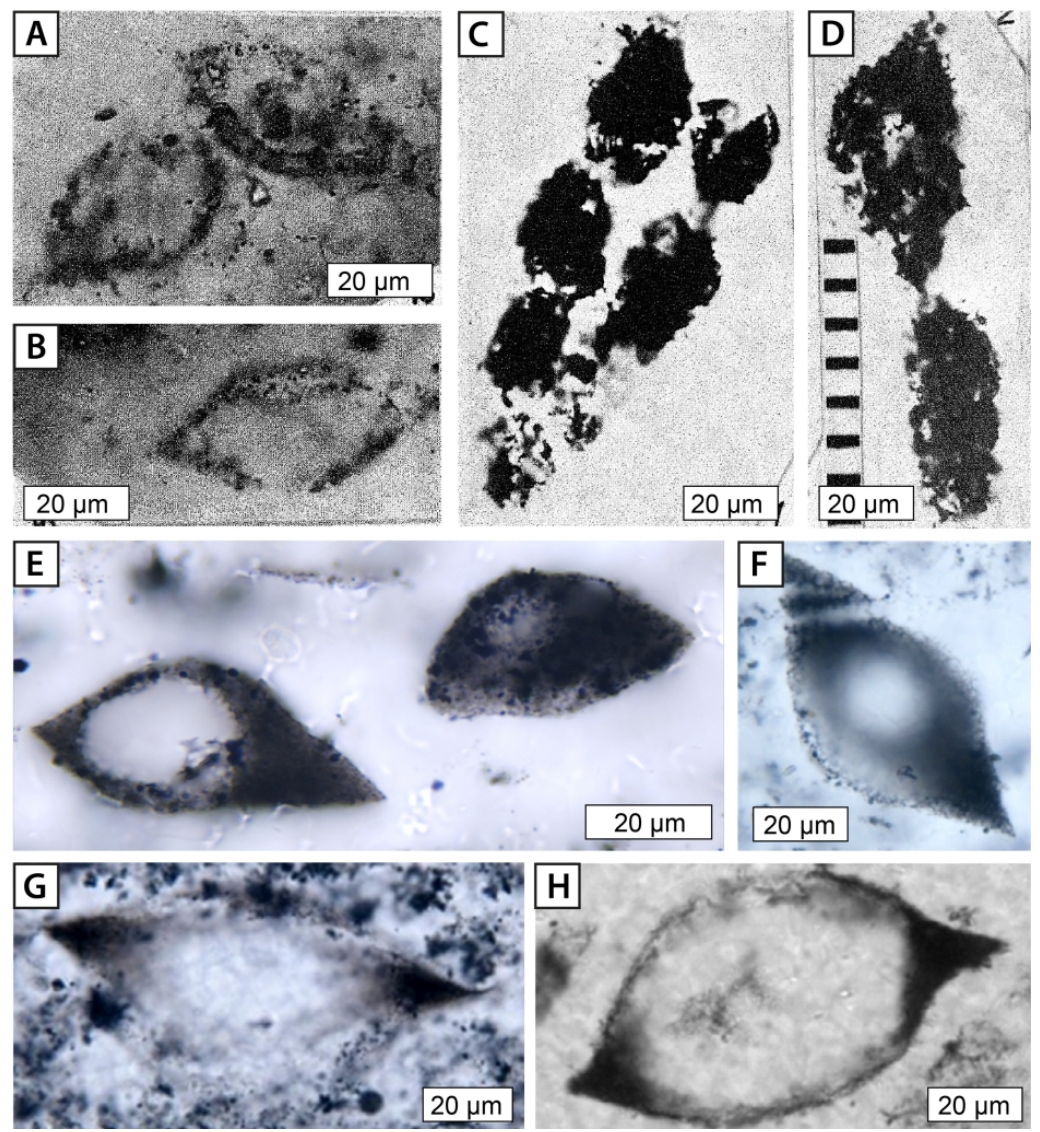

Fig. 8. Photomicrographs of lenticular structures interpreted as microfossils. A-D) Lenticular, disk-shaped objects with hollow centers and carbonaceous walls preserved in cherts from the Upper Onverwacht Group. Note that the structures occur isolated or in chain-like clusters of several specimen. (E-H) Morphologically very similar lenticular microfossils from the Buck Reef Chert. Images (A-D) from Pflug (1966); Images (EH) from Oehler et al. (2017), courtesy of Dorothy Z. Oehler. 

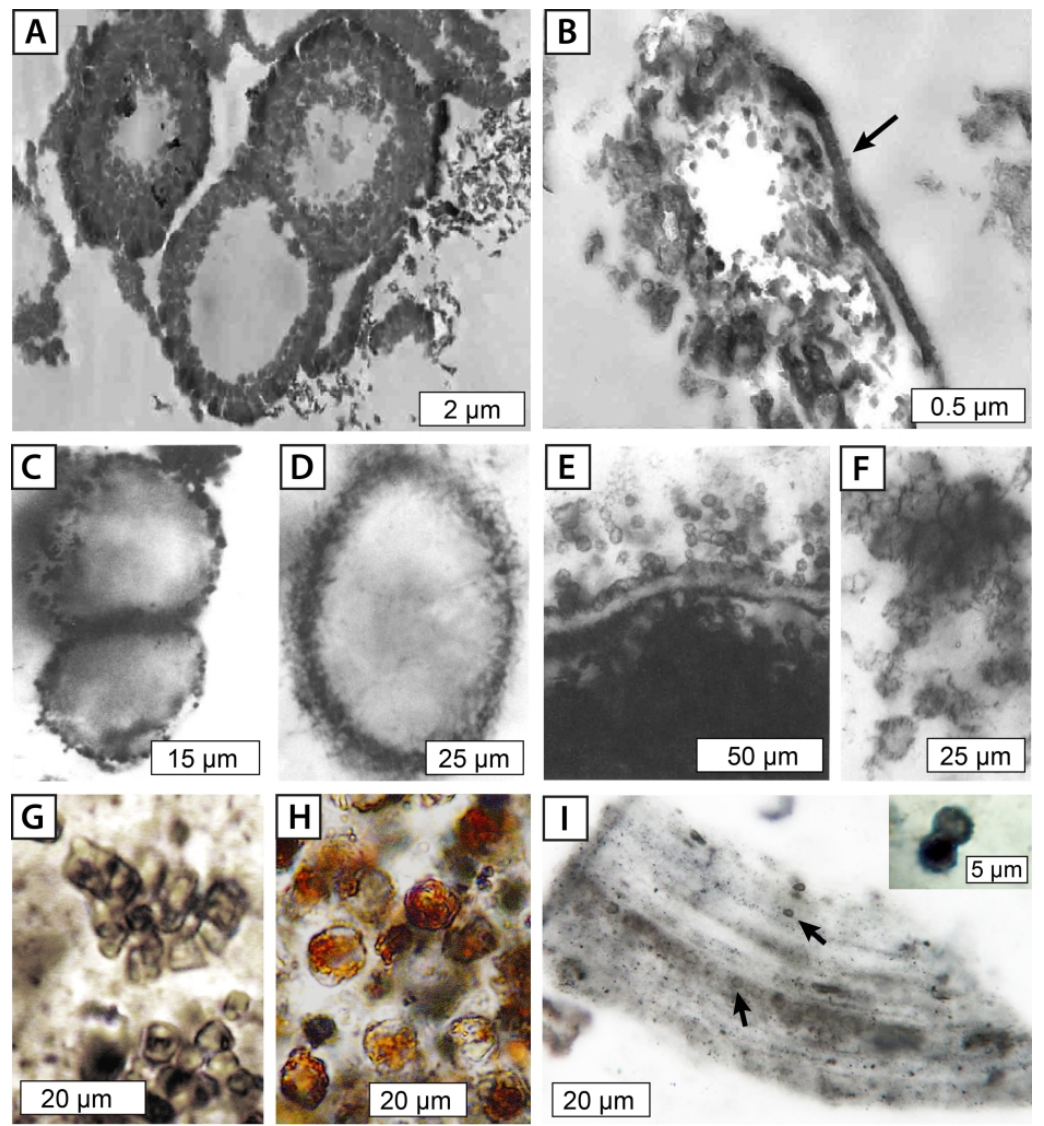

Fig. 9. Photomicrographs of proposed spheroidal microfossils from cherts of the Onverwacht Group. A and B) Transmission electron microscopy (TEM) images of cell-like objects with granular, in places detached walls (arrow) from the Hooggenoeg Formation. C and D) Large spheroids and ellipsoids from the Buck Reef Chert. E and F) Clusters of thin-walled spheroids from the Buck Reef Chert. G and H) Groups of spheroidal microstructures with rounded to angular walls from the Buck Reef Chert. I) Putative organic microspheres (arrows) from the Msauli Chert, which show features resembling cell division (small image in the upper right corner). Images (A-D) from Glikson et al. (2008); Images (C-F) from Walsh (1992); Images ( $G$ and $H)$ from Kremer and Kazmierczak (2017); Image (I) courtesy of Andrew H. Knoll. 

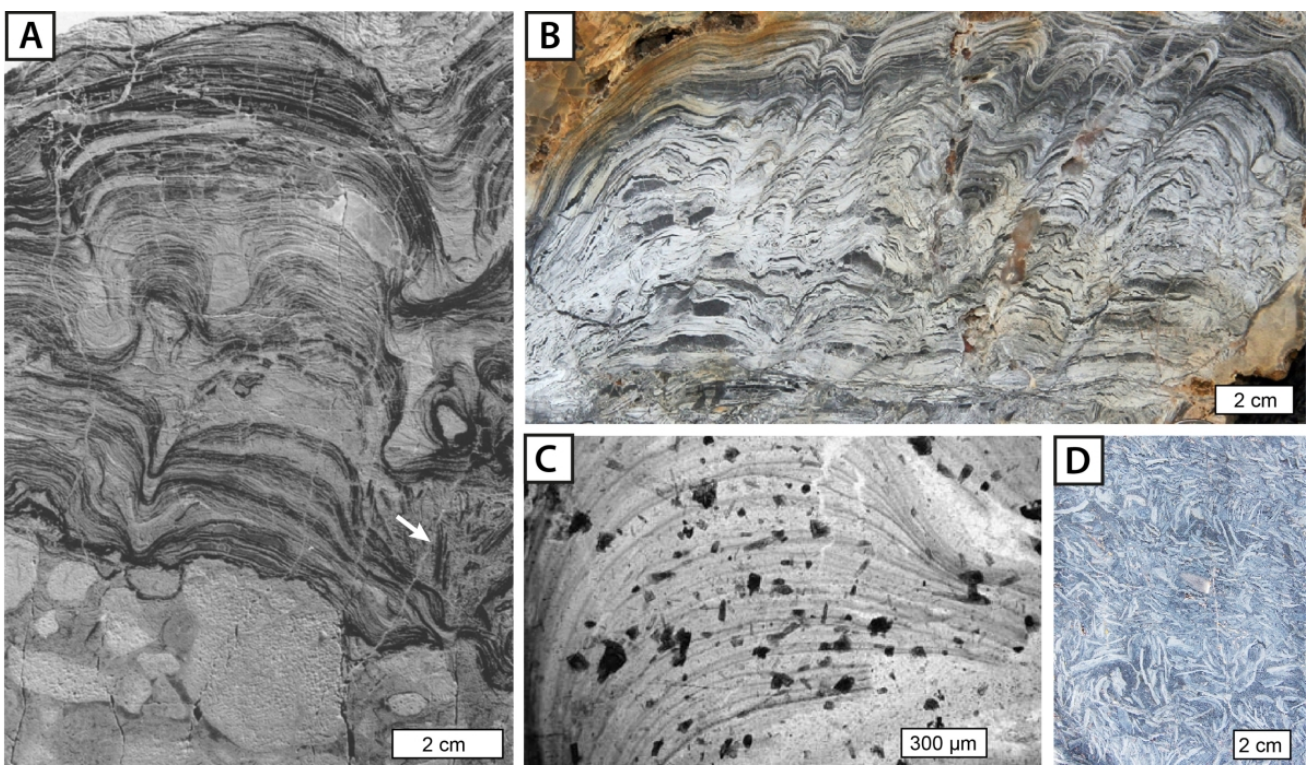

Fig. 10. Putative stromatolites and laminated silica crusts from the upper Onverwacht and Fig Tree Group. A) Polished slab showing morphologically diverse stromatolites overlying and draping the brecciated top of a komatiitic lava flow. Small basal domes successively grade into pseudocolumnar stromatolites with bridging laminations that are, in turn, overlain by low-relief domal laminations. Note the eroded stromatolite chips adjacent to the basal dome (arrow). B) Laminated silica crusts with inclined stromatolitelike columns and domes. C) Photomicrograph showing fine primary carbonaceous laminae with variable enrichment in secondary fine-grained tourmaline (dark minerals). D) Conglomerate of laminated silica chips interpreted as fragments of eroded stromatolites or sinter crusts. Images ( $A$ and $C$ ) from Byerly and Palmer (1991), (B and D) from Lowe and Byerly (2018). 


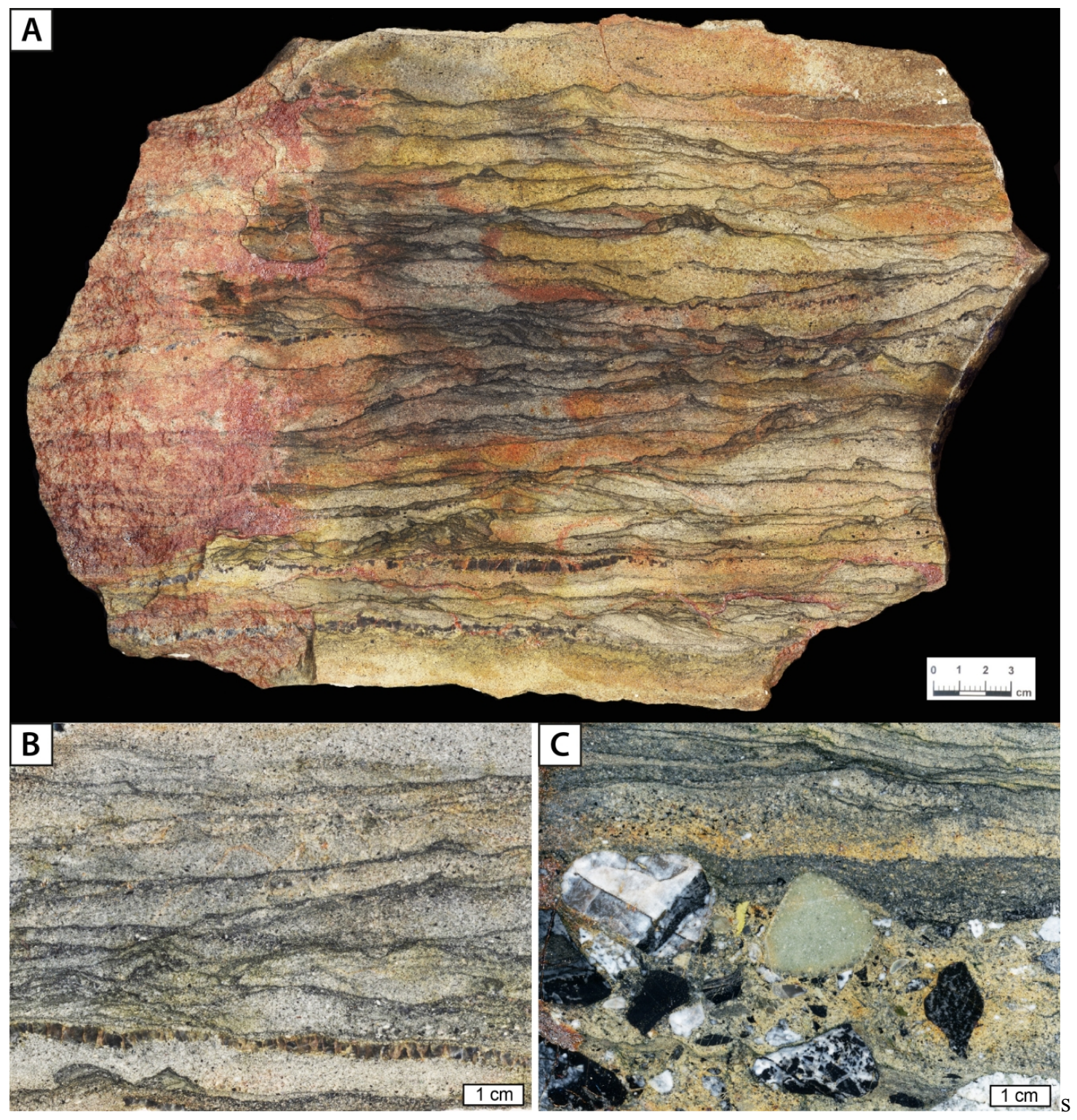

Fig. 11. Comparison of fossil microbial mats from tidal marine (A, B) and fluvial (C) deposits of the 3.22 Ga Moodies Group. A, B) Polished slab photographs of marine mats from the Saddleback Syncline showing densely spaced, crinkly carbonaceous laminations with small domes and tufts. The fossil mats are interbedded with medium- to coarse-grained sandstone and in places underlain by bedding-parallel chert lenses interpreted as silicified cavities. C) Terrestrial mats from the fluvial deposits of the Dycedale Syncline draping and onlapping interbedded clasts. Note that the preserved carbonaceous laminae are often thicker in comparison with the marine mats. 

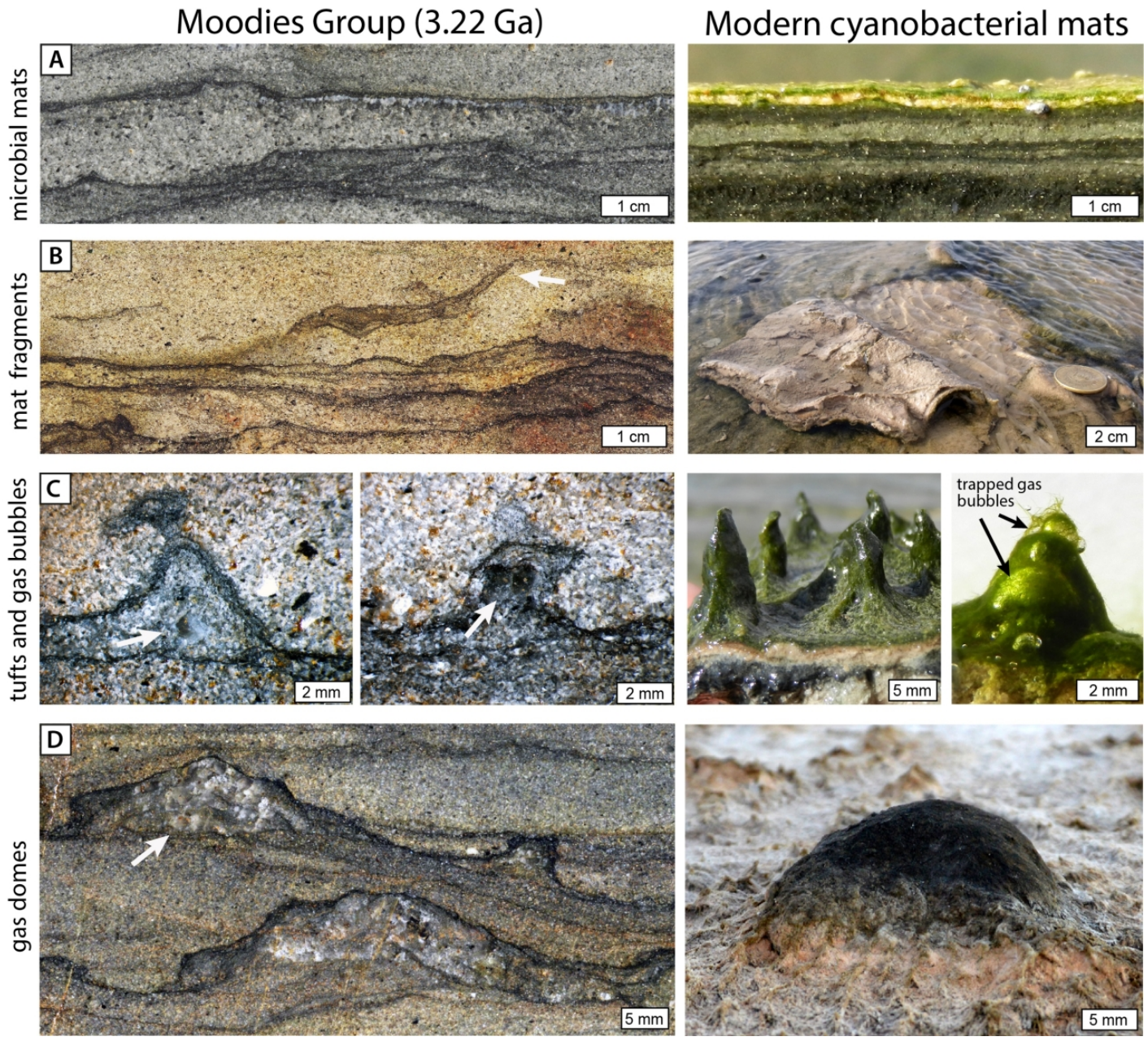

Fig. 12. Comparison of fossil intertidal microbial mats from the 3.22 Ga Moodies Group (left) with modern cyanobacterial mats from the tidal flats of Bahar Alouane, Tunisia (right). A) Crinkly carbonaceous mat laminations. B) Eroded mat fragment (arrow) and roll-up structure indicative for a cohesive consistency. C) Microbial tufts with now silicified cavities (arrows) interpreted as fossil gas bubbles, resembling trapped oxygen-rich bubbles in modern tufted mats. D) Silicified gas domes beneath the Moodies mats (arrow) and modern analogue of similar shape and size from Tunisia. 

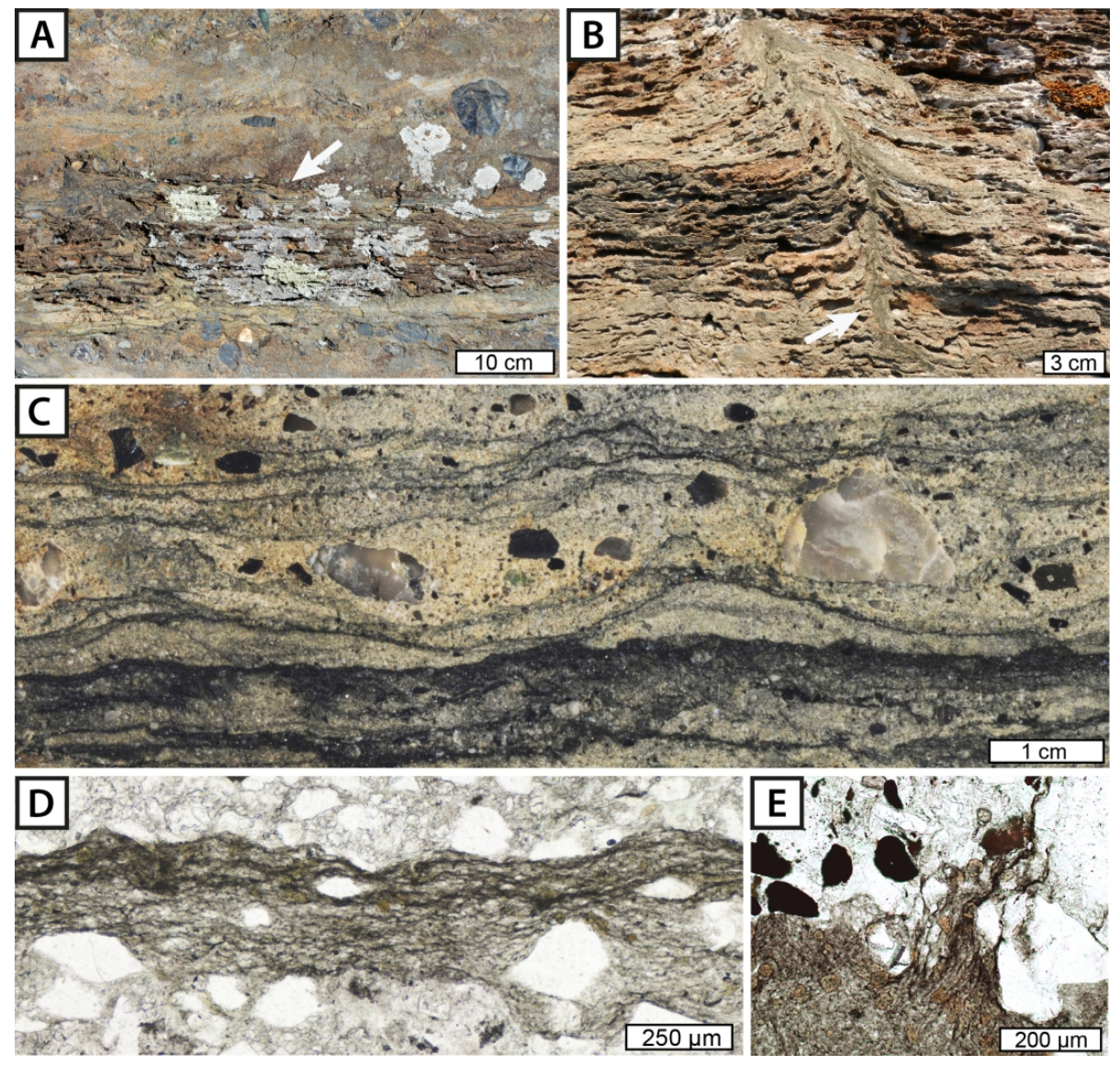

Fig. 13. Fossil terrestrial microbial mats from fluvial sandstones and conglomerates of the Moodies Group. A) Field photograph of the fluvial mats (arrow) interbedded with gravelly sandstones. B) Microbial mats disrupted and deformed by subvertical fluid-escape structure with well-defined central channel (arrow). C) Polished slab photograph with dark carbonaceous laminae of the fossil mats, draping former sedimentary surfaces and onlapping pebbles. D) Close-up view of the laminae, which show a dense meshwork of interwoven filamentous microstructures with trapped detrital grains. E) Filament-like microstructures in the upper, partially eroded part of the mat. Images (A-E) from Homann et al. (2018). 

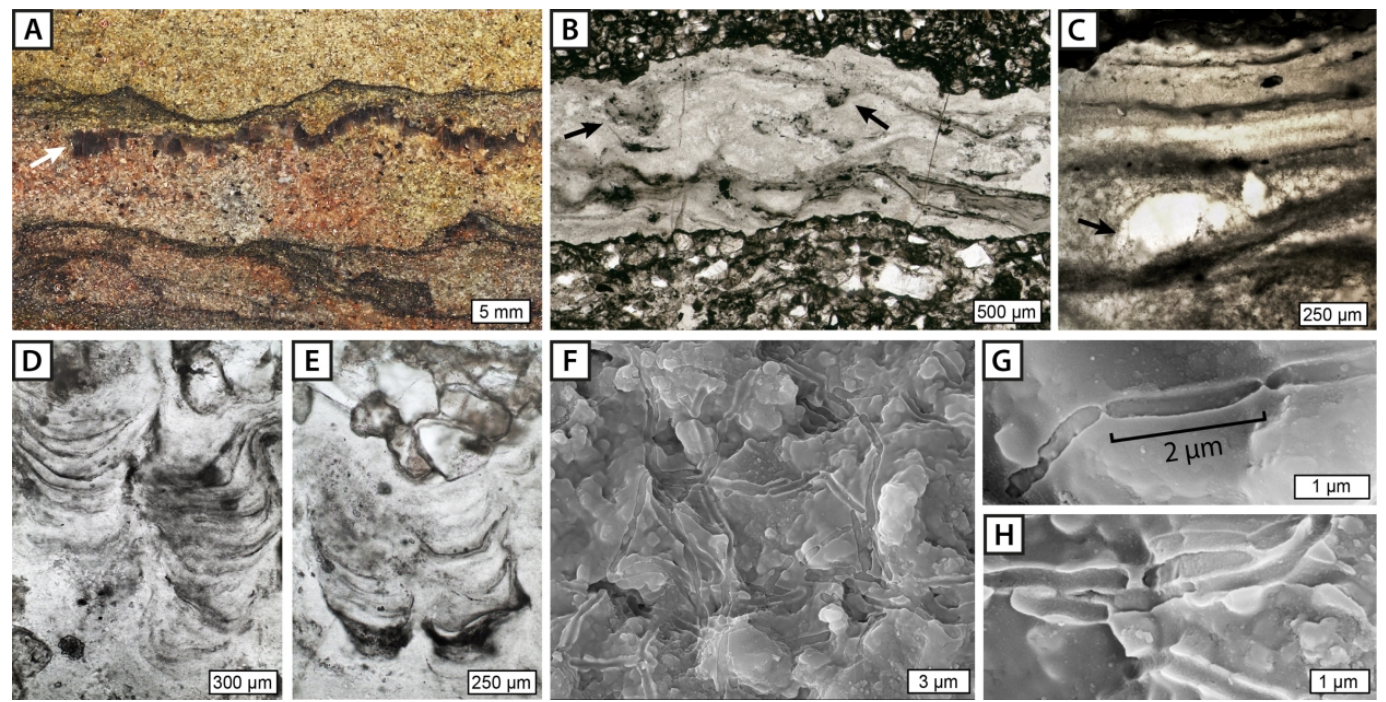

Fig. 14. Evidence for cavity-dwelling microbial life in the tidal deposits of the Moodies Group. A) Polished slab photograph showing silicified bedding-parallel cavity beneath fossil microbial mat (arrow). B) Photomicrograph of the silicified cavities with carbonaceous laminations, wisps, and pendant protrusions at the cavity ceiling (arrows). C) Carbonaceous laminae surrounding ovoid-shaped structure interpreted as trapped gas bubble (arrow). D and E) Close-up view of downward-facing columnar microstromatolites with preserved internal carbonaceous laminae. F) SEM image showing meshwork of filament molds embedded and permineralized in chert. $\mathrm{G}$ and $\mathrm{H}$ ) Filamentous molds with regularly, spaced, rod-shaped segments of approximately similar length. Images (B and D-H) from Homann et al. (2016).
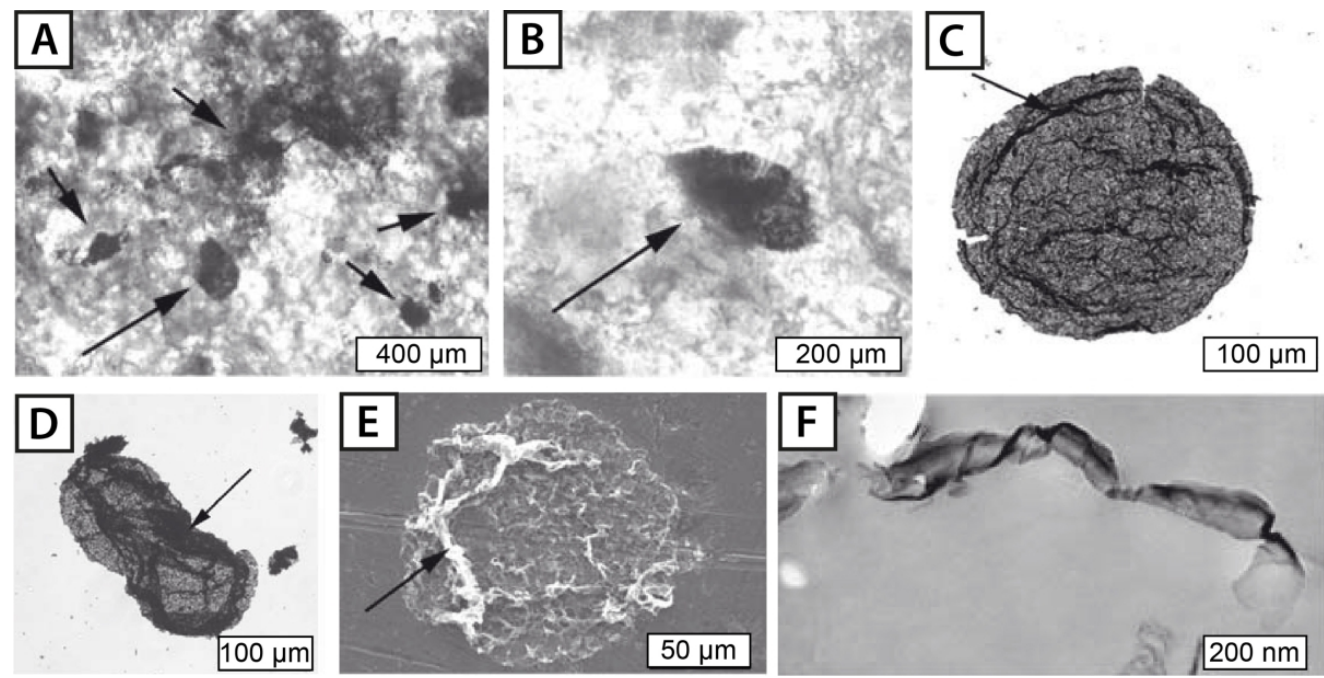

Fig. 15. Large organic-walled microfossils from the Moodies Group. A and B) Compressed spheroidal structures (arrows) in petrographic thin section. C and D) Microstructure extracted from the rock by acid maceration showing concentric folding (arrow in C) and collapse (arrow in D) of the wall. E) SEM image showing the folded, wrinkled and degraded texture of the wall (arrow). F) TEM image of ultrathin section showing homogenous ultrastructure of the torn and wrinkled 'cell' wall. Images (A-F) from Javaux et al. (2010). 
Pilbara

Greenstone Belts

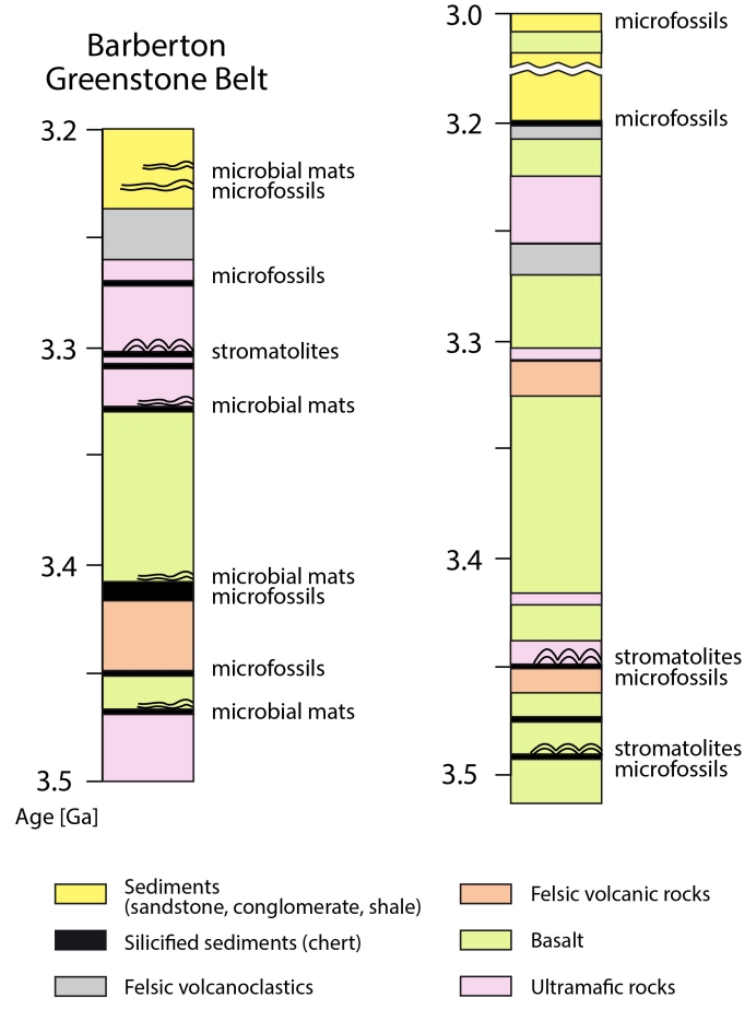

Fig. 15. Simplified stratigraphy and traces of early life in the Barberton Supergroup of South Africa in comparison with the Pilbara Supergroup of Western Australia. 


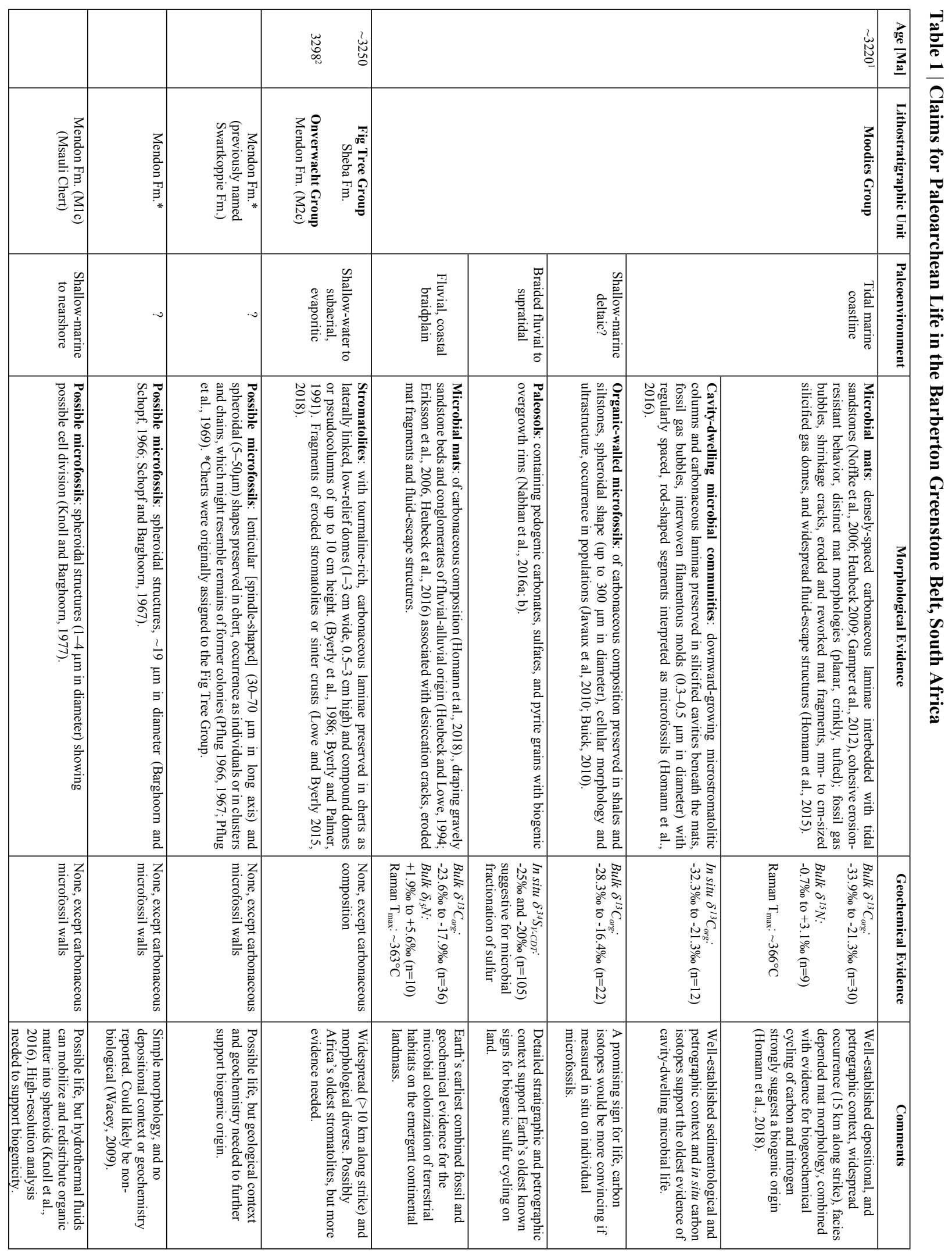




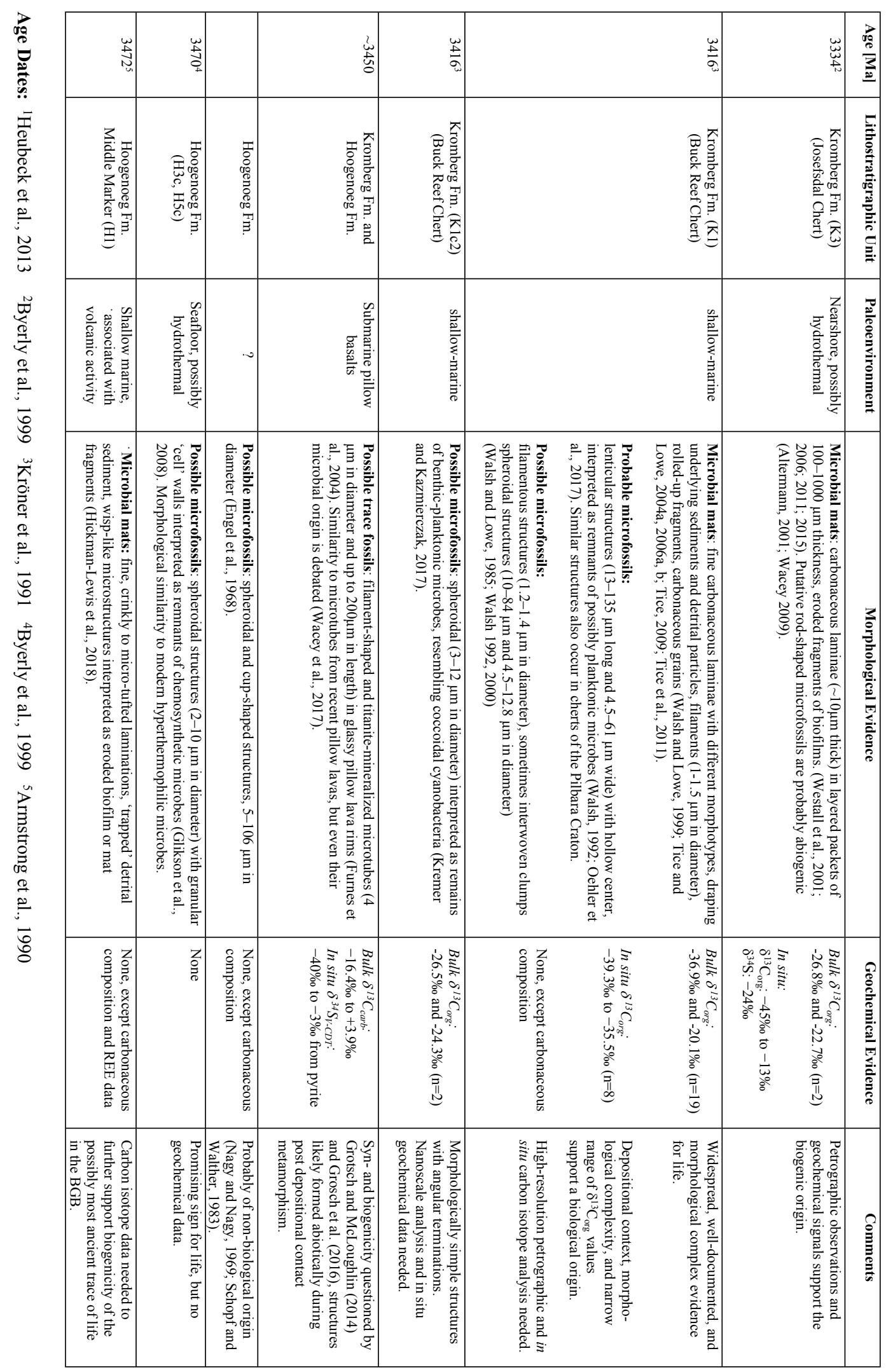

